Supporting information

\title{
Molecular Location Sensing Approach by Anisotropic Magnetism of An Endohedral Metallofullerene
}

Yuta Takano, ${ }^{*, 1}$ Ryo Tashita, ${ }^{2}$ Mitsuaki Suzuki, ${ }^{2,3}$ Shigeru Nagase, ${ }^{*, 4}$ Hiroshi Imahori, ${ }^{1,5}$ Takeshi Akasaka ${ }^{* 2,3,6,7}$

${ }^{1}$ Institute for Integrated Cell-Material Sciences (WPI-iCeMS), Kyoto University, Sakyo-ku, Kyoto 606-8501, Japan.

${ }^{2}$ Life Science Center of Tsukuba Advanced Research Alliance, University of Tsukuba, Tsukuba, Ibaraki 3058577, Japan.

${ }^{3}$ Department of Chemistry, Tokyo Gakugei University, Tokyo 184-8501, Japan

${ }^{4}$ Fukui Institute for Fundamental Chemistry, Kyoto University, Sakyo-ku, Kyoto 606-8103, Japan.

${ }^{5}$ Department of Molecular Engineering, Graduate School of Engineering, Kyoto University, Nishikyo-ku, Kyoto 615-8510, Japan.

${ }^{6}$ State Key Laboratory of Materials Processing and Die \& Mould Technology, School of Materials Science and Technology, Huazhong University of Science and Technology, Wuhan 430074, China.

${ }^{7}$ Foundation for Advancement of International Science, Tsukuba, Ibaraki 305-0821, Japan.

\section{AUTHORS EMAIL ADDRESS:}

(Y.T.) ytakano@icems.kyoto-u.ac.jp, (S.N.) nagase@ims.ac.jp, (T.A.) akasaka@tara.tsukuba.ac.jp

\section{Experimental Procedures:}

General. All chemicals and solvents were obtained from Wako Inc. or Sigma-Aldrich Inc. and used without further purification unless otherwise stated. La@ $C_{2 v}-\mathrm{C}_{82}{ }^{\mathrm{S} 1}$ and $\mathrm{Ce} @ C_{2 v}-\mathrm{C}_{82} \mathrm{~s} 2$ were prepared according to the reported procedures. 1,3,5-Trimethylbenzene (mesitylene) and $o$-DCB were distilled over benzophenone sodium ketyl under an argon atmosphere prior to use in a reaction. Analytical high-performance liquid chromatography (HPLC) was performed on a series of HPLC apparatus (Jasco Inc.) using 5PYE, Buckyprep, or 5PBB columns $(4.6 \times 250 \mathrm{~mm}$; Nacalai Tesque Inc.). Preparative HPLC was performed on a HPLC apparatus LC-908 C60 (Japan Analytical Industry Inc.) using 5PYE, Buckyprep, or 5PBB columns (20 × 250 $\mathrm{mm}$; Nacalai Tesque Inc.). Monitoring absorption was carried out at $330 \mathrm{~nm}$, and toluene was used as an eluent for HPLC. The ${ }^{1} \mathrm{H}-\mathrm{NMR}$ measurements were conducted on a spectrometer (AVANCE 500; Bruker Analytik $\mathrm{GmbH}$ ) with a CryoProbe system, where TMS was used as an internal reference ( $\delta=0.00 \mathrm{ppm})$. Absorption spectra were recorded using a spectrophotometer (UV-3150; Shimadzu Corp.). Mass spectrometry was conducted using a mass spectrometer (BIFLEX III; Bruker Analytik GmbH) with 1,1,4,4-tetraphenyl-1,3butadiene as a matrix. Electron paramagnetic resonance (EPR) spectra were recorded by a Bruker EMXPlus9.5/2.7. The spectrometer was operated at $9.8 \mathrm{GHz}$ with a microwave power of $0.2 \mathrm{~mW}(30 \mathrm{~dB})$, a modulation frequency of $100 \mathrm{kHz}$, and modulation amplitude of $300 \mathrm{mG}$. The $g$ values were determined by the readout function of the spectrometer with the weak pitch as a standard, while the hyperfine splitting constants were measured using a Hall unit for calibration of the magnetic field. 
Synthesis of compound 1a-e. To a $1.0 \mathrm{mM}$ solution of Ce@ $\mathrm{C}_{82}(9.9 \mathrm{mg}, 9.0 \mu \mathrm{mol})$ in $o$-DCB $(9 \mathrm{~mL})$ poured in a Pyrex tube, $9.0 \mathrm{~mL}$ of mesitylene was added and deoxygenated by argon gas bubbling for $15 \mathrm{~min}$. Then, the solution was degassed by freezing-thaw cycle under a reduced pressure for three times, and illuminated by a high pressure mercury lamp for $50 \mathrm{sec}$. The reaction solution was injected to the HPLC system with a preparative column as shown in Fig. S1 to isolate the target compounds from byproducts and unreacted starting materials.

Ce $@ \mathbf{C}_{82}\left(\mathbf{C H}_{2}-3,5-\mathbf{C}_{6} \mathbf{H}_{3} \mathbf{M e}_{2}\right)$ (1a). Yield $19 \%,{ }^{1} \mathrm{H}$ NMR (500MHz, $\left.\mathrm{CS}_{2} / \mathrm{CD}_{2} \mathrm{Cl}_{2}=3 / 1(\mathrm{v} / \mathrm{v}), 293 \mathrm{~K}\right): \delta 8.67$ (o$\mathrm{H}, \mathrm{s}, 2 \mathrm{H}), 7.67(p-\mathrm{H}, \mathrm{s}, 1 \mathrm{H}), 6.36\left(\mathrm{CH}_{2}, \mathrm{~d}, 1 \mathrm{H}, J=11.5 \mathrm{~Hz}\right), 6.24\left(\mathrm{CH}_{2}, \mathrm{~d}, 1 \mathrm{H}, J=11.5 \mathrm{~Hz}\right), 3.07\left(\mathrm{CH}_{3}, \mathrm{~s}, 6 \mathrm{H}\right)$ ppm. Vis-NIR $\left(\mathrm{CS}_{2}\right): \lambda_{\max }=573,810,1011 \mathrm{~nm}$. MALDI-TOF MS m/z: calcd for $\mathrm{CeC}_{91} \mathrm{H}_{11}\left([\mathrm{M}]^{-}\right), 1244.20$; found, 1244.20.

Ce $@ \mathbf{C}_{82}\left(\mathbf{C H}_{2}-\mathbf{3 , 5}-\mathbf{C}_{\mathbf{6}} \mathbf{H}_{3} \mathbf{M e}\right.$ ) (1b). Yield $12 \%,{ }^{1} \mathrm{H}$ NMR (500MHz, $\left.\mathrm{CS}_{2} / \mathrm{CD}_{2} \mathrm{Cl}_{2}=3 / 1(\mathrm{v} / \mathrm{v}), 293 \mathrm{~K}\right): \delta 7.12(o-$ $\mathrm{H}, \mathrm{s}, 2 \mathrm{H}), 7.04(p-\mathrm{H}, \mathrm{s}, 1 \mathrm{H}), 4.09\left(\mathrm{CH}_{2}, \mathrm{~d}, 1 \mathrm{H}, J=12.5 \mathrm{~Hz}\right), 4.06\left(\mathrm{CH}_{2}, \mathrm{~d}, 1 \mathrm{H}, J=12.5 \mathrm{~Hz}\right), 2.42\left(\mathrm{CH}_{3}, \mathrm{~s}, 6 \mathrm{H}\right)$ ppm. Vis-NIR $\left(\mathrm{CS}_{2}\right): \lambda_{\max }=577,1309 \mathrm{~nm}$. MALDI-TOF MS m/z: calcd for $\mathrm{CeC}_{91} \mathrm{H}_{11}\left([\mathrm{M}]^{-}\right), 1244.20$; found, 1244.20.

Ce@ $\mathbf{C}_{82}\left(\mathbf{C H}_{2}-\mathbf{3}, \mathbf{5}-\mathbf{C}_{6} \mathbf{H}_{3} \mathbf{M e}_{2}\right)$ (1c). Yield $16 \%,{ }^{1} \mathrm{H}$ NMR (500MHz, $\left.\mathrm{CS}_{2} / \mathrm{CD}_{2} \mathrm{Cl}_{2}=3 / 1(\mathrm{v} / \mathrm{v}), 293 \mathrm{~K}\right): \delta 7.05(o-$ $\mathrm{H}, \mathrm{s}, 2 \mathrm{H}), 6.85(p-\mathrm{H}, \mathrm{s}, 1 \mathrm{H}), 4.41\left(\mathrm{CH}_{2}, \mathrm{~d}, 1 \mathrm{H}, J=14.0 \mathrm{~Hz}\right), 4.15\left(\mathrm{CH}_{2}, \mathrm{~d}, 1 \mathrm{H}, J=14.0 \mathrm{~Hz}\right), 3.05\left(\mathrm{CH}_{3}, \mathrm{~s}, 6 \mathrm{H}\right)$ ppm. Vis-NIR $\left(\mathrm{CS}_{2}\right): \lambda_{\max }=565,984,1394 \mathrm{~nm}$. MALDI-TOF MS m/z: calcd for $\mathrm{CeC}_{91} \mathrm{H}_{11}\left([\mathrm{M}]^{-}\right), 1244.20$; found, 1244.20.

Ce $@ \mathbf{C}_{82}\left(\mathbf{C H}_{2}-3,5-\mathbf{C}_{6} \mathbf{H}_{3} \mathbf{M e}_{2}\right)$ (1d). Yield $24 \%,{ }^{1} \mathrm{H}$ NMR (500MHz, $\left.\mathrm{CS}_{2} / \mathrm{CD}_{2} \mathrm{Cl}_{2}=3 / 1(\mathrm{v} / \mathrm{v}), 293 \mathrm{~K}\right): \delta 8.29(o-$ $\mathrm{H}, \mathrm{s}, 2 \mathrm{H}), 7.36(p-\mathrm{H}, \mathrm{s}, 1 \mathrm{H}), 6.10\left(\mathrm{CH}_{2}, \mathrm{~d}, 1 \mathrm{H}, J=12.3 \mathrm{~Hz}\right), 5.88\left(\mathrm{CH}_{2}, \mathrm{~d}, 1 \mathrm{H}, J=12.3 \mathrm{~Hz}\right), 2.71\left(\mathrm{CH}_{3}, \mathrm{~s}, 6 \mathrm{H}\right)$ ppm. Vis-NIR $\left(\mathrm{CS}_{2}\right): \lambda_{\max }=562,794,990,1279 \mathrm{~nm}$. MALDI-TOF MS $m / z$ : calcd for $\mathrm{CeC}_{91} \mathrm{H}_{11}\left([\mathrm{M}]^{-}\right)$, 1244.20; found, 1244.20.

Black crystals of $\mathbf{1 d} \cdot 1\left(\mathrm{CS}_{2}\right)$ were obtained by liquid-liquid bilayer diffusion methods of a solution of $\mathbf{1 d}$ in $\mathrm{CS}_{2}$ and hexane used as a poor solvent. Single-crystal X-ray diffraction measurements were performed at $90 \mathrm{~K}$ on a Bruker AXS machine equipped with an Apex II CCD detector with Mo K $\alpha$ radiation $(\lambda=0.71073 \AA$ ).

The multi-scan method was used for absorption corrections. The structures were solved by direct methods and were refined using SHELXL-2014/7. ${ }^{\mathrm{S} 3}$ Crystal data of 1d·1CS 2 : $\mathrm{C}_{92} \mathrm{H}_{11} \mathrm{CeS}_{2}, M=1320.25,0.87 \mathrm{~mm} \times 0.25$ $\mathrm{mm} \times 0.13 \mathrm{~mm}$, Orthorhombic, space group Pnma (No. 62), $a=20.9653(6) \AA, b=15.2285(4) \AA, c=$ 14.6886(4) ̊, $V=4689.6(2) \AA^{3}, \lambda=0.71073 \AA, T=90 \mathrm{~K}, Z=4, \rho_{\text {calc }}=1.870 \mathrm{~g} \mathrm{~cm}^{-3}, \mu$ (Mo $\left.K \alpha\right)=1.128 \mathrm{~mm}$ ${ }^{1}, \theta=1.69-27.10^{\circ} ; R_{1}=0.1231, \mathrm{wR}_{2}=0.3169$ for all data; $\mathrm{R}_{1}=0.0986, \mathrm{wR}_{2}=0.2772$ for 5361 reflections $(I$ $>2.0 \sigma(I)$ ) with 856 parameters refined using 859 restraints. CCDC number: 1456504.

Ce $@ \mathbf{C}_{82}\left(\mathbf{C H}_{2}-3,5-\mathbf{C}_{6} \mathbf{H}_{3} \mathbf{M e}_{2}\right)$ (1e). Yield $6 \%$, Vis-NIR $\left(\mathrm{CS}_{2}\right): \lambda_{\max }=1289,1539 \mathrm{~nm}$. MALDI-TOF MS $m / z$ : calcd for $\mathrm{CeC}_{91} \mathrm{H}_{11}\left([\mathrm{M}]^{-}\right), 1244.20$; found, 1244.21 .

Synthesis of compound 2a-e. To a $1.0 \mathrm{mM}$ solution of $\mathrm{La} @ \mathrm{C}_{82}(9.9 \mathrm{mg}, 9.0 \mu \mathrm{mol})$ in $o$-DCB $(9 \mathrm{~mL})$ poured in a Pyrex tube, $9.0 \mathrm{~mL}$ of mesitylene was added and deoxygenated by argon gas bubbling for $15 \mathrm{~min}$. Then, the solution was degassed by freezing-thaw cycle under a reduced pressure for three times, and illuminated by a high pressure mercury lamp for $50 \mathrm{sec}$. The reaction solution was injected to the HPLC system with a preparative column as shown in Fig. S2 to isolate the target compounds from byproducts and unreacted 
starting materials. After the isolation, EPR spectra of 2a-e were also measured and found to be EPR silent (not shown), indicating their closed-shell electronic structures.

$\mathbf{L a} @ \mathbf{C}_{82}\left(\mathbf{C H}_{2}-3,5-\mathbf{C}_{6} \mathbf{H}_{3} \mathbf{M e}_{2}\right)$ (2a). Yield $17 \%,{ }^{1} \mathrm{H}$ NMR (500MHz, $\mathrm{CS}_{2} / \mathrm{CD}_{2} \mathrm{Cl}_{2}=3 / 1$ (v/v), 293K): $\delta$ 6.94.67 (o-H, s, 2H), $6.91(p-\mathrm{H}, \mathrm{s}, 1 \mathrm{H}), 4.08\left(\mathrm{CH}_{2}, \mathrm{~d}, 1 \mathrm{H}, J=12.5 \mathrm{~Hz}\right), 4.00\left(\mathrm{CH}_{2}, \mathrm{~d}, 1 \mathrm{H}, J=12.5 \mathrm{~Hz}\right), 2.29$ $\left(\mathrm{CH}_{3}, \mathrm{~s}, 6 \mathrm{H}\right) \mathrm{ppm}$. Vis-NIR $\left(\mathrm{CS}_{2}\right): \lambda_{\max }=573,810,1011 \mathrm{~nm}$. MALDI-TOF MS m/z: Calcd for $\mathrm{LaC}_{91} \mathrm{H}_{11}$ $\left([\mathrm{M}]^{-}\right), 1243.0$; found, 1243.0.

La@ $@ \mathbf{C}_{\mathbf{8 2}}\left(\mathbf{C H}_{\mathbf{2}}-\mathbf{3 , 5}-\mathbf{C}_{\mathbf{6}} \mathbf{H}_{3} \mathbf{M e}_{2}\right)$ (2b). Yield $11 \%,{ }^{1} \mathrm{H}$ NMR (500MHz, $\mathrm{CS}_{2} / \mathrm{CD}_{2} \mathrm{Cl}_{2}=3 / 1$ (v/v), 293K): $\delta 7.42$ $(o-\mathrm{H}, \mathrm{s}, 2 \mathrm{H}), 7.13(p-\mathrm{H}, \mathrm{s}, 1 \mathrm{H}), 4.79\left(\mathrm{CH}_{2}, \mathrm{~d}, 1 \mathrm{H}, J=12.5 \mathrm{~Hz}\right), 4.69\left(\mathrm{CH}_{2}, \mathrm{~d}, 1 \mathrm{H}, J=12.5 \mathrm{~Hz}\right), 2.41\left(\mathrm{CH}_{3}, \mathrm{~s}\right.$, $6 \mathrm{H}) \mathrm{ppm}$. Vis-NIR $\left(\mathrm{CS}_{2}\right): \lambda_{\max }=577,1309 \mathrm{~nm}$. MALDI-TOF MS $m / z$ : Calcd for $\mathrm{LaC}_{91} \mathrm{H}_{11}\left([\mathrm{M}]^{-}\right), 1243.0$; found, 1243.0.

La@ $@ \mathbf{C}_{\mathbf{8 2}}\left(\mathbf{C H}_{\mathbf{2}}-\mathbf{3 , 5}-\mathbf{C}_{\mathbf{6}} \mathbf{H}_{3} \mathbf{M e} \mathbf{2}_{2}\right)$ (2c). Yield $15 \%,{ }^{1} \mathrm{H}$ NMR (500MHz, $\left.\mathrm{CS}_{2} / \mathrm{CD}_{2} \mathrm{Cl}_{2}=3 / 1(\mathrm{v} / \mathrm{v}), 293 \mathrm{~K}\right): \delta 6.90$ $(o-\mathrm{H}, \mathrm{s}, 2 \mathrm{H}), 6.85(p-\mathrm{H}, \mathrm{s}, 1 \mathrm{H}), 3.57\left(\mathrm{CH}_{2}, \mathrm{~d}, 1 \mathrm{H}, J=13.0 \mathrm{~Hz}\right), 3.53\left(\mathrm{CH}_{2}, \mathrm{~d}, 1 \mathrm{H}, J=13.0 \mathrm{~Hz}\right), 2.31\left(\mathrm{CH}_{3}, \mathrm{~s}\right.$, $6 \mathrm{H}) \mathrm{ppm}$. Vis-NIR $\left(\mathrm{CS}_{2}\right): \lambda_{\max }=565,984,1394 \mathrm{~nm}$. MALDI-TOF MS m/z: Calcd for $\mathrm{LaC}_{91} \mathrm{H}_{11}\left([\mathrm{M}]^{-}\right)$, 1243.0; found, 1243.0.

La@ $@ \mathbf{C}_{\mathbf{8 2}}\left(\mathbf{C H}_{\mathbf{2}}-\mathbf{3 , 5}-\mathbf{C}_{\mathbf{6}} \mathbf{H}_{3} \mathbf{M e}\right.$ ) (2d). Yield $22 \%,{ }^{1} \mathrm{H}$ NMR (500MHz, $\left.\mathrm{CS}_{2} / \mathrm{CD}_{2} \mathrm{Cl}_{2}=3 / 1(\mathrm{v} / \mathrm{v}), 293 \mathrm{~K}\right): \delta 7.41$ $(p-\mathrm{H}, \mathrm{s}, 1 \mathrm{H}), 6.94(o-\mathrm{H}, \mathrm{s}, 2 \mathrm{H}), 4.36\left(\mathrm{CH}_{2}, \mathrm{~d}, 1 \mathrm{H}, J=13.0 \mathrm{~Hz}\right), 4.32\left(\mathrm{CH}_{2}, \mathrm{~d}, 1 \mathrm{H}, J=13.0 \mathrm{~Hz}\right), 2.33\left(\mathrm{CH}_{3}, \mathrm{~s}\right.$, $6 \mathrm{H}) \mathrm{ppm}$. Vis-NIR $\left(\mathrm{CS}_{2}\right): \lambda_{\max }=562,794,990,1279 \mathrm{~nm}$. MALDI-TOF MS $m / z$ : Calcd for $\mathrm{LaC}_{91} \mathrm{H}_{11}\left([\mathrm{M}]^{-}\right)$, 1243.0; found, 1243.0.

$\mathbf{L a} @ \mathbf{C}_{82}\left(\mathbf{C H}_{2}-\mathbf{3 , 5}-\mathbf{C}_{6} \mathbf{H}_{3} \mathbf{M e}_{2}\right)$ (2e). Yield $6 \%$, Vis-NIR $\left(\mathrm{CS}_{2}\right): \lambda_{\max }=1289,1539 \mathrm{~nm}$. MALDI-TOF MS $\mathrm{m} / z$ : Calcd for $\mathrm{LaC}_{91} \mathrm{H}_{11}\left([\mathrm{M}]^{-}\right), 1243.0$; found, 1243.0.

\section{Theoretical calculations:}

All theoretical calculations were conducted using the Gaussion09 Revision D.01 program. ${ }^{\mathrm{S}}$ Unrestricted B3LYP $,{ }^{\mathrm{S5}} \mathrm{B} 3 \mathrm{LYP}-\mathrm{D} 3,{ }^{\mathrm{S} 6}$ or M06-2X $\mathrm{X}^{\mathrm{S} 7}$ was used as a functional and $3-21 \mathrm{G},{ }^{\mathrm{S}}{ }^{6} 6-31 \mathrm{G},{ }^{\mathrm{S} 9}$ or $6-31 \mathrm{G}(\mathrm{d}){ }^{\mathrm{S} 10}$ was used as a basis set with the SDD relativistic effective core potential ${ }^{\mathrm{S} 11}$ for the metal atoms.

To select the appropriate computing method and level of theory, several computed structures were compared with the crystal structure of 1d, which is derived from the addition position C10 (Table S1). Among the various methods, the B3LYP/3-21G was found to be the best to reproduce the distances between the Ce atom and the nearest six carbon atoms configuring the hexagon. In addition, the B3LYP/3-21G with SDD also reproduced well the distance between the $\mathrm{Ce}$ atom and the hydrogen atom at the para position in the addend. Although it is known that the computing methods using B3LYP-D3 and M06-2X can consider the dispersion force, it was found that the present levels of theory would overestimate the force to reproduce the real structures in the present study. Consequently, the B3LYP/3-21G with SDD is selected as the appropriate method to optimize the structure for the present study to finish the calculations in reasonable computing time.

Anisotropic axis derived from a metal atom was predicted by the local electric field around the atom which was calculated by the Gaussian09 package as electrostatic properties with using "Prop" keyword. ${ }^{\text {S12 }}$ 


\section{References:}

S1. Yamamoto, K.; Funasaka, H.; Takahashi, T.; Akasaka, T.; Suzuki, T.; Maruyama, Y. J. Phys. Chem. 1994, $98,12831-12833$.

S2. Wakahara, T.; Kobayashi, J.; Yamada, M.; Maeda, Y.; Tsuchiya, T.; Okamura, M.; Akasaka, T.; Waelchli, M.; Kobayashi, K.; Nagase, S.; Kato, T.; Kako, M.; Yamamoto, K.; Kadish, K. M. J. Am. Chem. Soc. 2004, $126,4883-4887$.

S3. Sheldrick, G. M. SHELXTL Version 2014/7. http://shelx.uni-ac.gwdg.de/SHELX/index.php.

S4. Frisch, M. J.; Trucks, G. W.; Schlegel, H. B.; Scuseria, G. E.; Robb, M. A.; Cheeseman, J. R.; Scalmani, G.; Barone, V.; Mennucci, B.; Petersson, G. A.; Nakatsuji, H.; Caricato, M.; Li, X.; Hratchian, H. P.; Izmaylov, A. F.; Bloino, J.; Zheng, G.; Sonnenberg, J. L.; Hada, M.; Ehara, M.; Toyota, K.; Fukuda, R.; Hasegawa, J.; Ishida, M.; Nakajima, T.; Honda, Y.; Kitao, O.; Nakai, H.; Vreven, T.; Montgomery, Jr., J. A.; Peralta, J. E.; Ogliaro, F.; Bearpark, M.; Heyd, J. J.; Brothers, E.; Kudin, K. N.; Staroverov, V. N.; Kobayashi, R.; Normand, J.; Raghavachari, K.; Rendell, A.; Burant, J. C.; Iyengar, S. S.; Tomasi, J.; Cossi, M.; Rega, N.; Millam, J. M.; Klene, M.; Knox, J. E.; Cross, J. B.; Bakken, V.; Adamo, C.; Jaramillo, J.; Gomperts, R.; Stratmann, R. E.; Yazyev, O.; Austin, A. J.; Cammi, R.; Pomelli, C. J.; Ochterski, W.; Martin, R. L.; Morokuma, K.; Zakrzewski, V. G.; Voth, G. A.; Salvador, P.; Dannenberg, J. J.; Dapprich, S.; Daniels, A. D.; Farkas, O.; Foresman, J. B.; Ortiz, J. V.; Cioslowski, J.; Fox, D. J. GAUSSIAN 09, Revision D.01; Gaussian, Inc., Wallingford CT, 2009.

S5. (a) Becke, A. D. Phys. Rev. A 1988, 38, 3098-3100. (b) Lee, C. T.; Yang, W. T.; Parr, R. G. Physical Review B 1988, 37, 785-789. (c) Francl, M. M.; Pietro, W. J.; Hehre, W. J.; Binkley, J. S.; Gordon, M. S.; Defrees, D. J.; Pople, J. A. J. Chem. Phys. 1982, 77, 3654-3665. Becke, A. D. J. Chem. Phys. 1993, 98, 56485652.

S6. Grimme, S.; Antony, J.; Ehrlich, S.; Krieg, H. J. Chem. Phys. 2010, 132, 154104.

S7. Zhao, Y.; Truhlar, D. G. Theor. Chem. Acc. 2008, 120, 215-241.

S8. Binkley, J. S.; Pople, J. A.; Hehre, W. J. J. Am. Chem. Soc. 1980, 102, 939-947.

S9. (a) Ditchfie, R; Hehre, W. J.; Pople, J. A. J. Chem. Phys. 1971, 54, 724-728. (b) Hehre, W. J.; Ditchfie, R; Pople, J. A. J. Chem. Phys. 1972, 56, 2257-2261.

S10. (a) Petersson, G. A.; Bennett, A.; Tensfeldt, T. G.; Allaham, M. A.; Shirley, W. A.; Mantzaris, J. J. Chem. Phys. 1988, 89, 2193-2218. (b) Petersson, G. A.; Allaham, M. A. J. Chem. Phys. 1991, 94, 6081-6090.

S11. Cao, X. Y.; Dolg, M. J. Mol. Struc. Theochem. 2002, 581, 139-147.

S12. Barone, V.; Recent advances in density functional methods, Part I; Chong D. P. Ed.; World Scientific Publ. Co. Singapore, 1996.

S13. Takano, Y.; Aoyagi, M.; Yamada, M.; Nikawa, H.; Slanina, Z.; Mizorogi, N.; Ishitsuka, M. O.; Tsuchiya, T.; Maeda, Y.; Akasaka, T.; Kato, T.; Nagase, S. J. Am. Chem. Soc. 2009, 131, 9340-9346.

S14. (a) Chilton, N. F.; Collison, D.; McInnes, E. J. L.; Winpenny, R. E. P.; Soncini, A. Nat. Commun. 2013, 4, 2551. (b) Chilton, N. F.; Langley, S. K.; Moubaraki, B.; Soncini, A.; Batten, S. R.; Murray, K. S. Chem. Sci. 2013, 4, 1719-1730. 
a

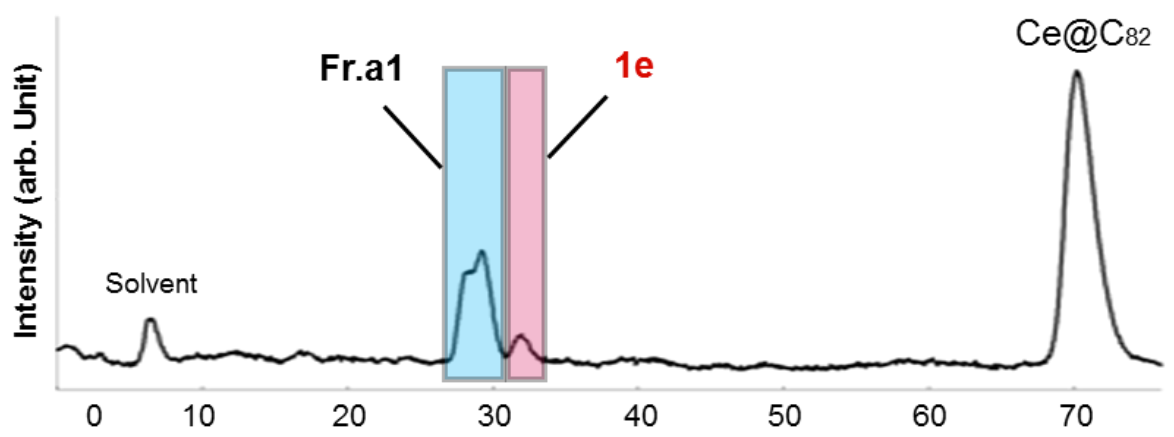

b

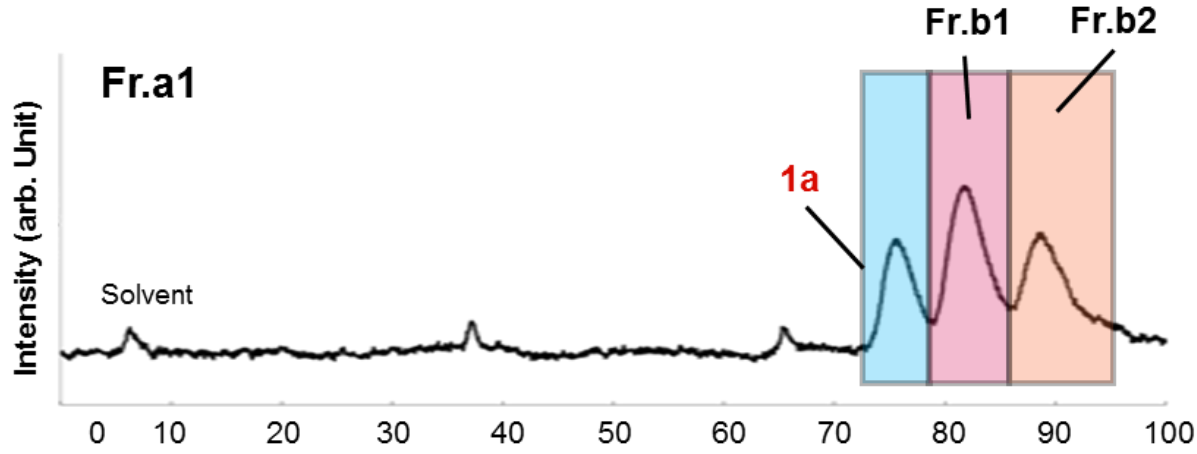

C

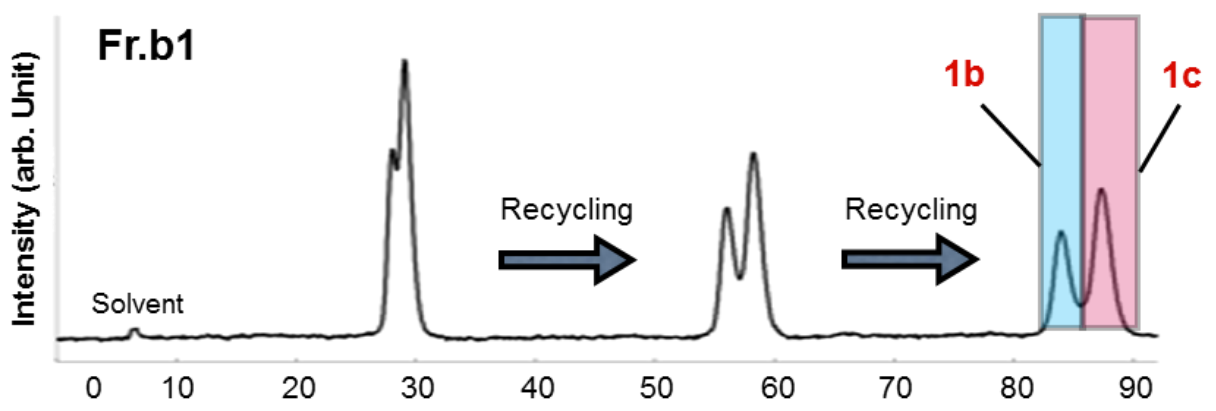

d

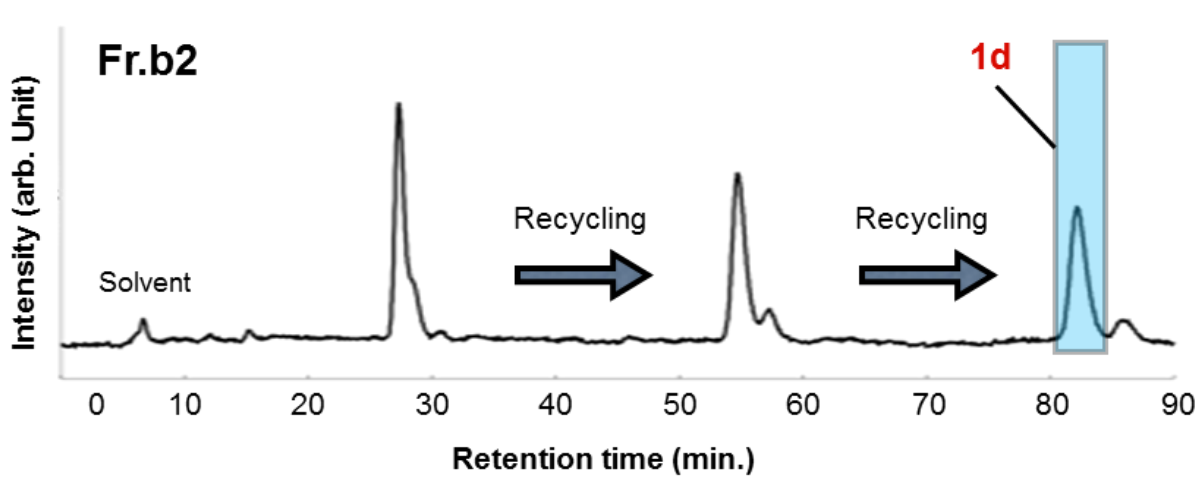

Figure S1. HPLC profiles of the reaction crude of 1. (a) The first stage. Column: Buckyprep $\varphi 20 \times 250 \mathrm{~mm}$, eluent: toluene, flow rate: $9.99 \mathrm{~mL} / \mathrm{min}$, wavelength: $330 \mathrm{~nm}$, temperature: r.t. (b) The second stage. Column: 5PBB $\varphi 20 \times 250 \mathrm{~mm}$, eluent: toluene, flow rate: $9.99 \mathrm{~mL} / \mathrm{min}$, wavelength: $330 \mathrm{~nm}$, temperature: r.t. (c) The last stage. Column: Buckyprep $\varphi 20 \times 250 \mathrm{~mm}$, eluent: toluene, flow rate: $9.99 \mathrm{~mL} / \mathrm{min}$, wavelength: $330 \mathrm{~nm}$, temperature: r.t. (d) The last stage. Column: Buckyprep $\varphi 20 \times 250 \mathrm{~mm}$, eluent: toluene, flow rate: 9.99 $\mathrm{mL} / \mathrm{min}$, wavelength: $330 \mathrm{~nm}$, temperature: r.t. 


\section{a}

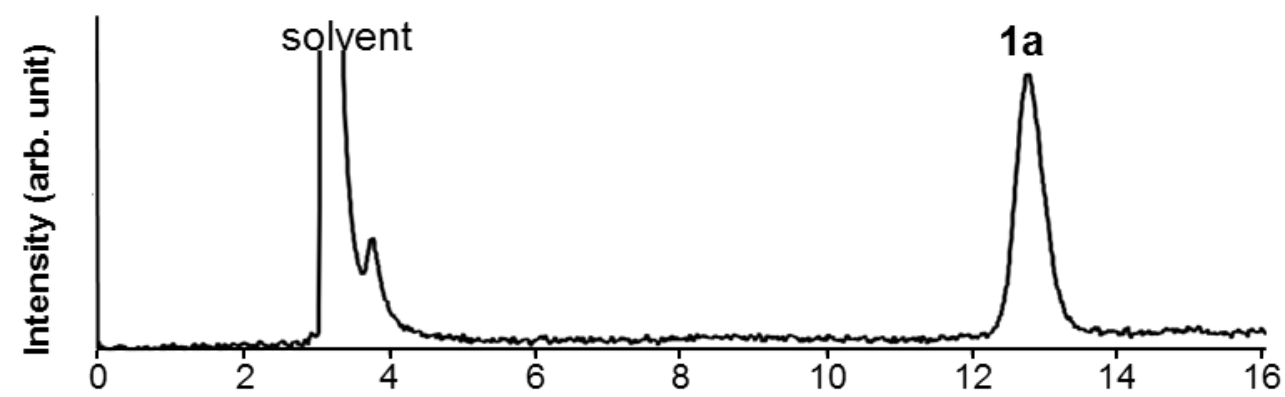

b
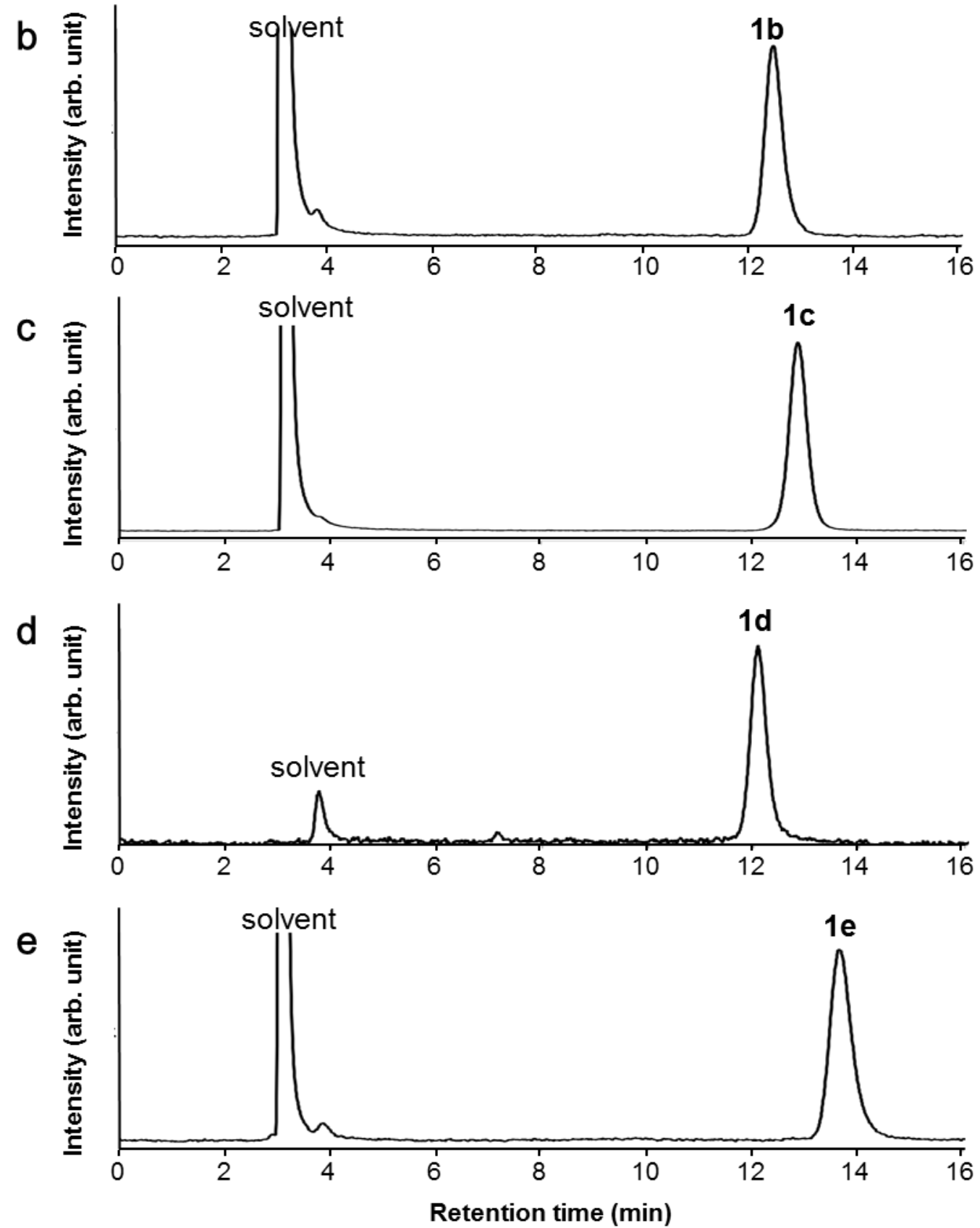

Figure S2. HPLC profiles of the isolated (a) 1a, (b) 1b, (c) 1c, (d) 1d, and (e) 1e. Column size: $\varphi 4.6 \times 250$ $\mathrm{mm}$, eluent: toluene, flow rate: $1.0 \mathrm{~mL} / \mathrm{min}$, wavelength: $330 \mathrm{~nm}$, temperature: $40^{\circ} \mathrm{C}$. 
a

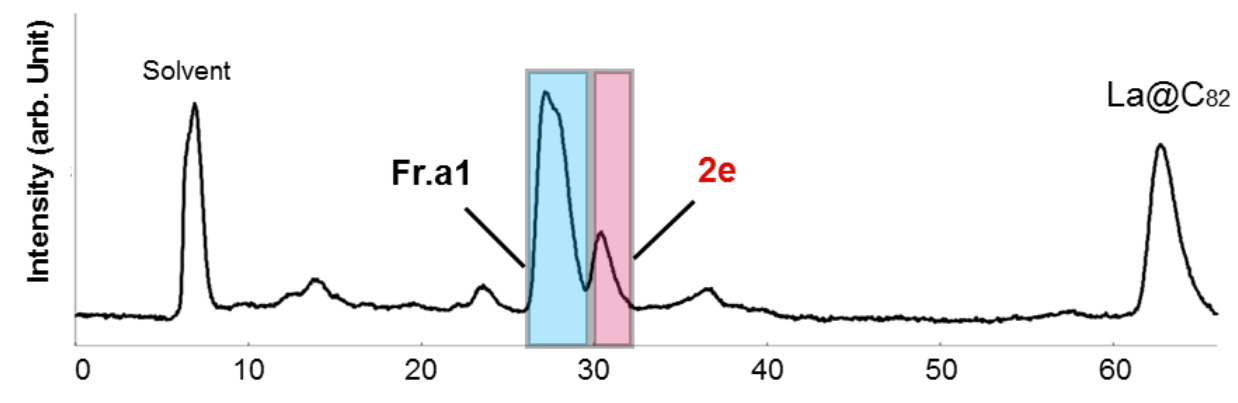

b
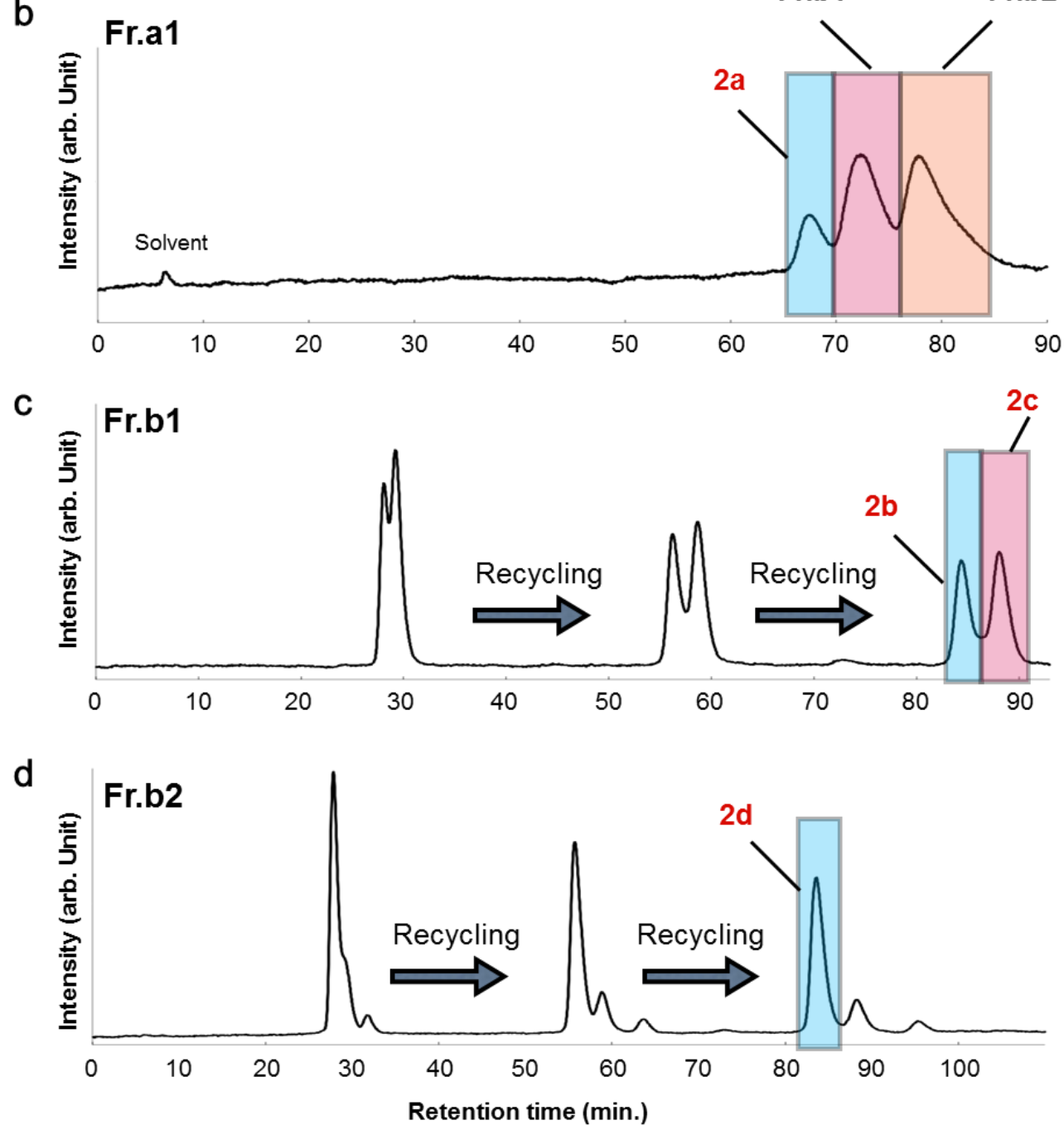

Figure S3. HPLC profiles of the reaction crude of 2. (a) The first stage. Column: Buckyprep $\varphi 20 \times 250 \mathrm{~mm}$, eluent: toluene, flow rate: $9.99 \mathrm{~mL} / \mathrm{min}$, wavelength: $330 \mathrm{~nm}$, temperature: r.t. (b) The second stage. Column: 5PBB $\varphi 20 \times 250 \mathrm{~mm}$, eluent: toluene, flow rate: $9.99 \mathrm{~mL} / \mathrm{min}$, wavelength: $330 \mathrm{~nm}$, temperature: r.t. (c) The last stage. Column: Buckyprep $\varphi 20 \times 250 \mathrm{~mm}$, eluent: toluene, flow rate: $9.99 \mathrm{~mL} / \mathrm{min}$, wavelength: $330 \mathrm{~nm}$, temperature: r.t. (d) The last stage. Column: Buckyprep $\varphi 20 \times 250 \mathrm{~mm}$, eluent: toluene, flow rate: 9.99 $\mathrm{mL} / \mathrm{min}$, wavelength: $330 \mathrm{~nm}$, temperature: r.t. 
a

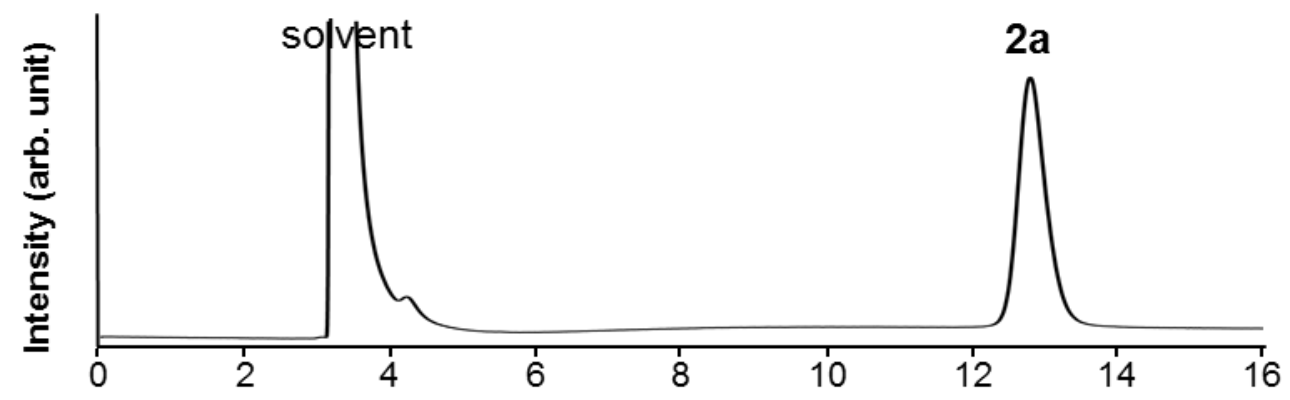

b
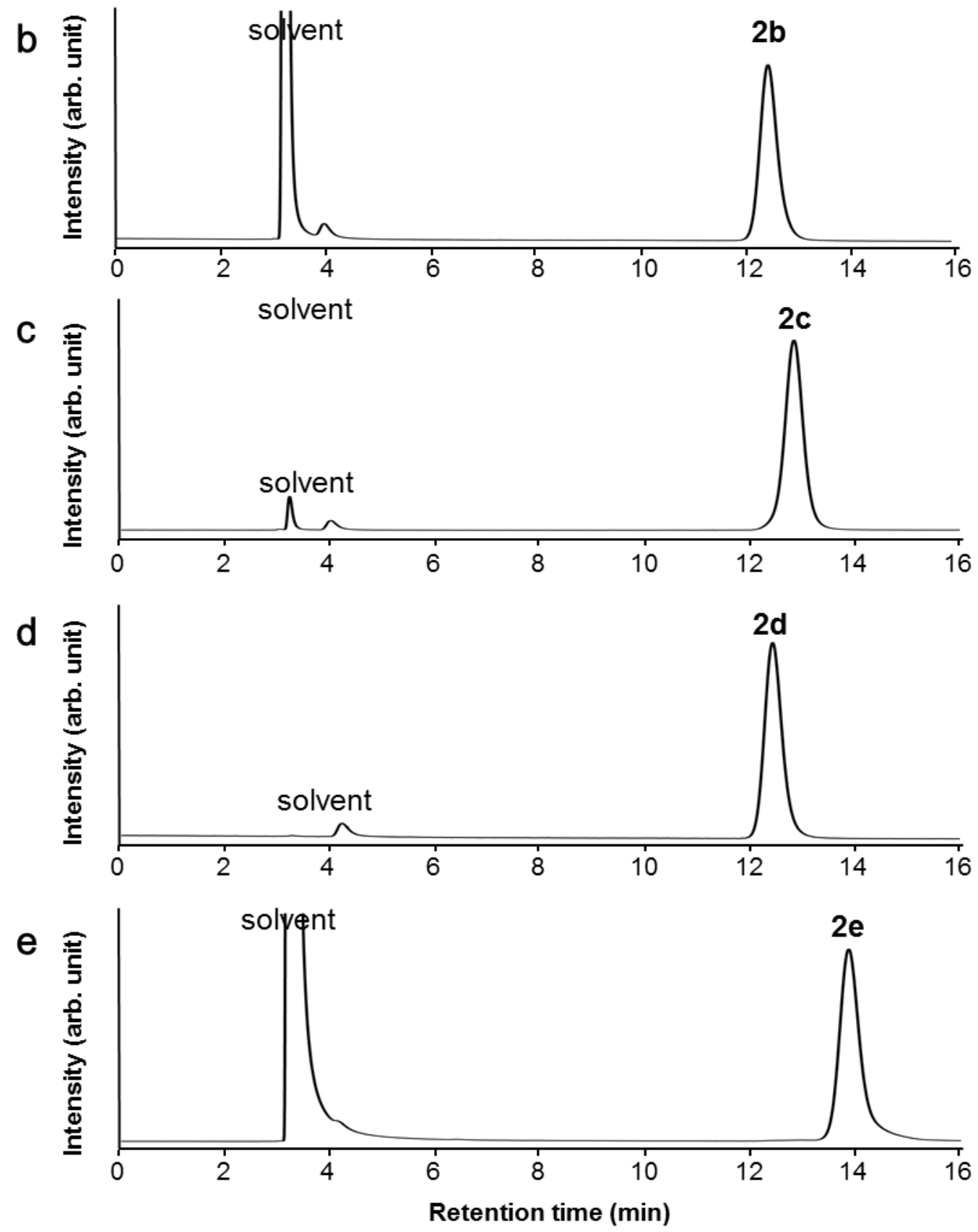

Figure S4. HPLC profiles of the isolated (a) 2a, (b) 2b, (c) 2c, (d) 2d, and (e) 2e. Column size: $\varphi 4.6 \times 250$ $\mathrm{mm}$, eluent: toluene, flow rate: $1.0 \mathrm{~mL} / \mathrm{min}$, wavelength: $330 \mathrm{~nm}$, temperature: $40^{\circ} \mathrm{C}$. 


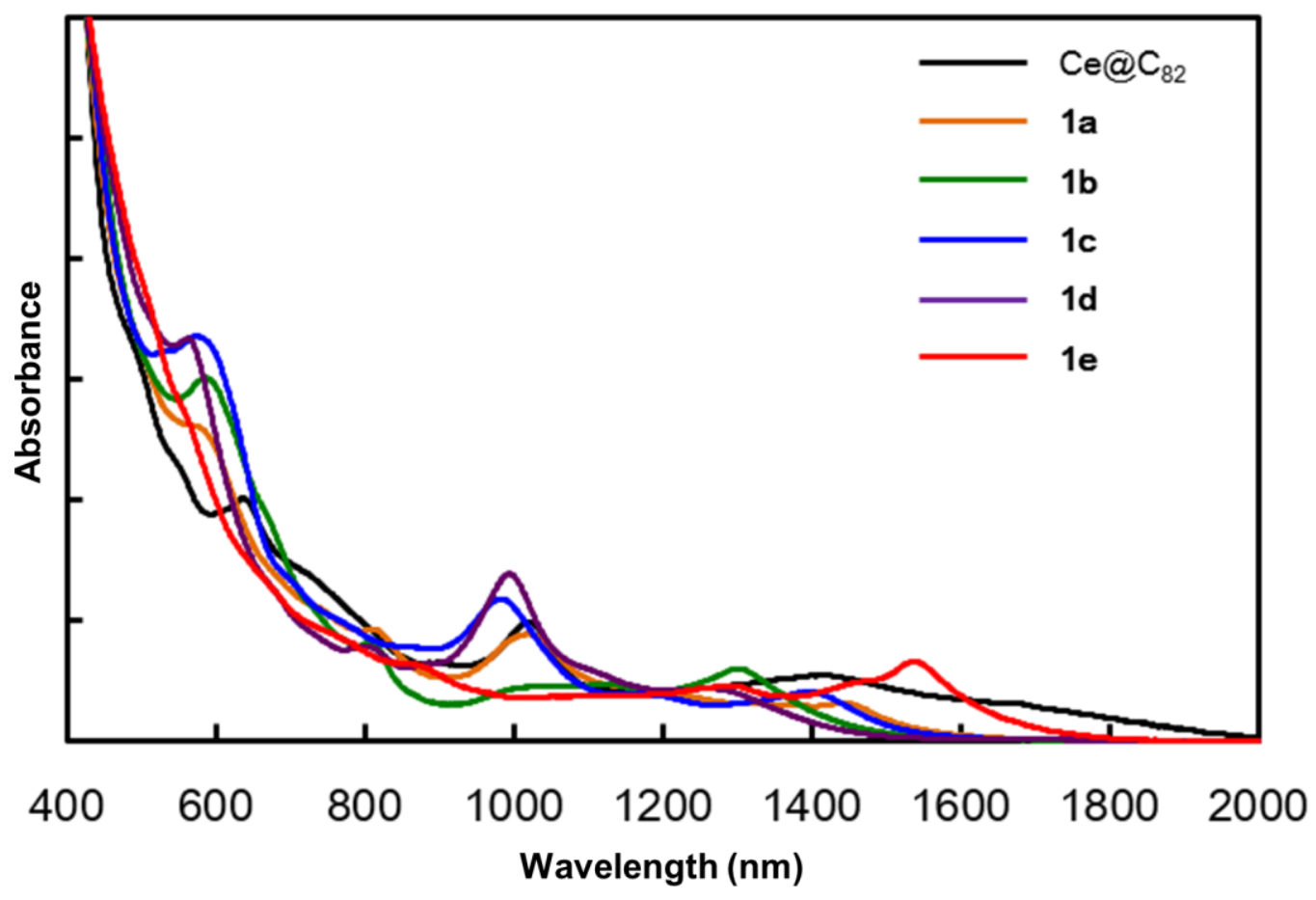

Figure S5. Vis-Near IR absorption spectra of 1a-e in $\mathrm{CS}_{2}$.

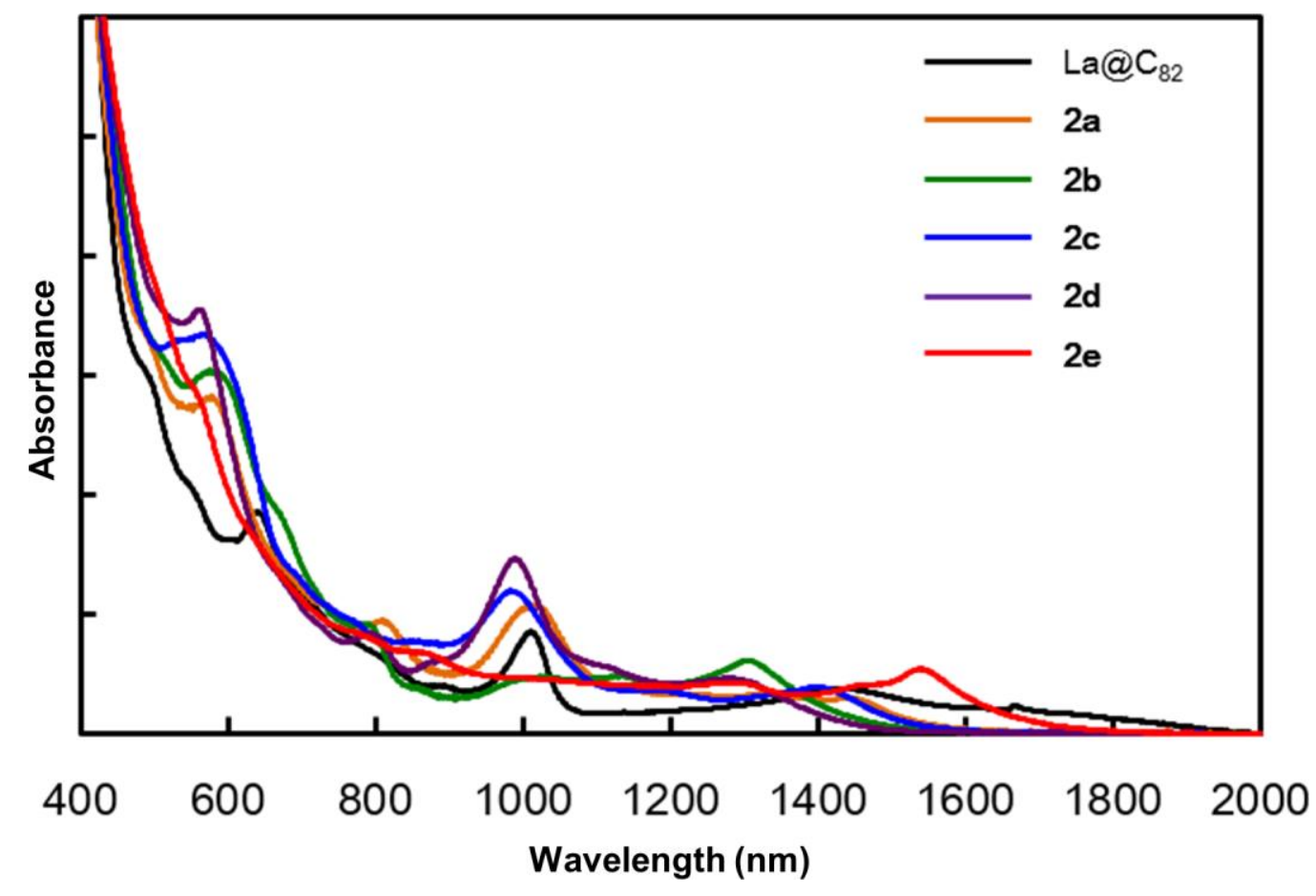

Figure S6. Vis-Near IR absorption spectra of 2a-e in $\mathrm{CS}_{2}$. 
a

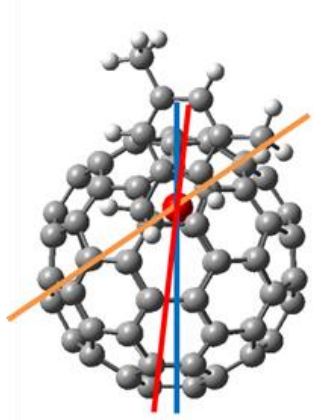

b

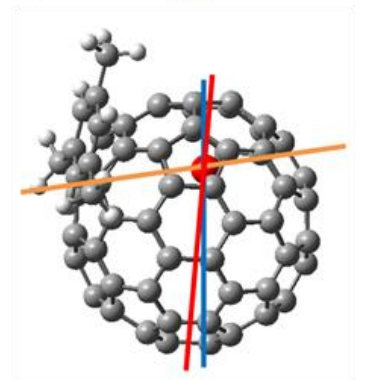

C

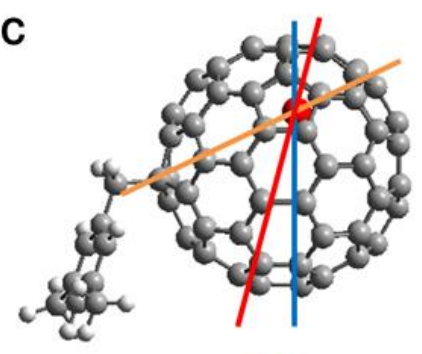

d

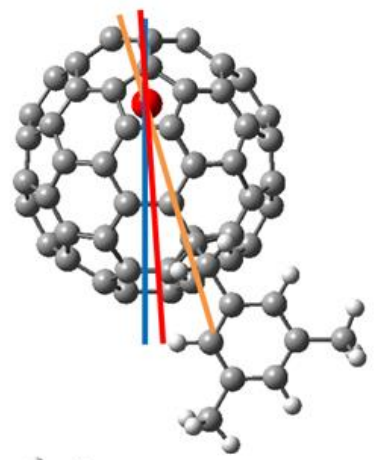

e

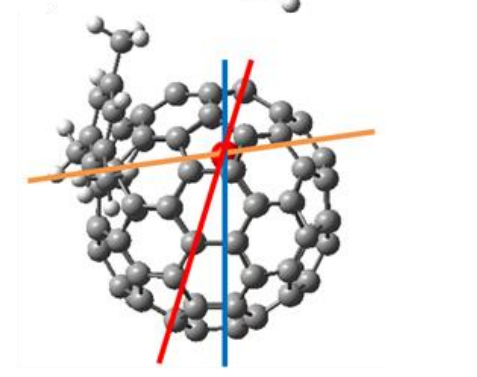

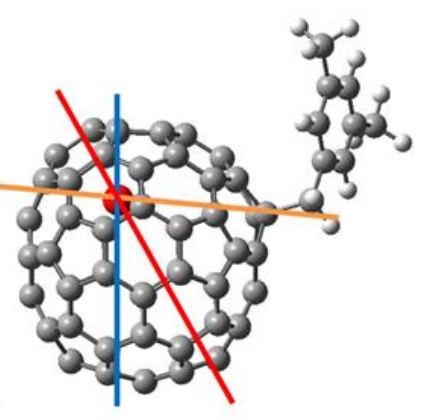
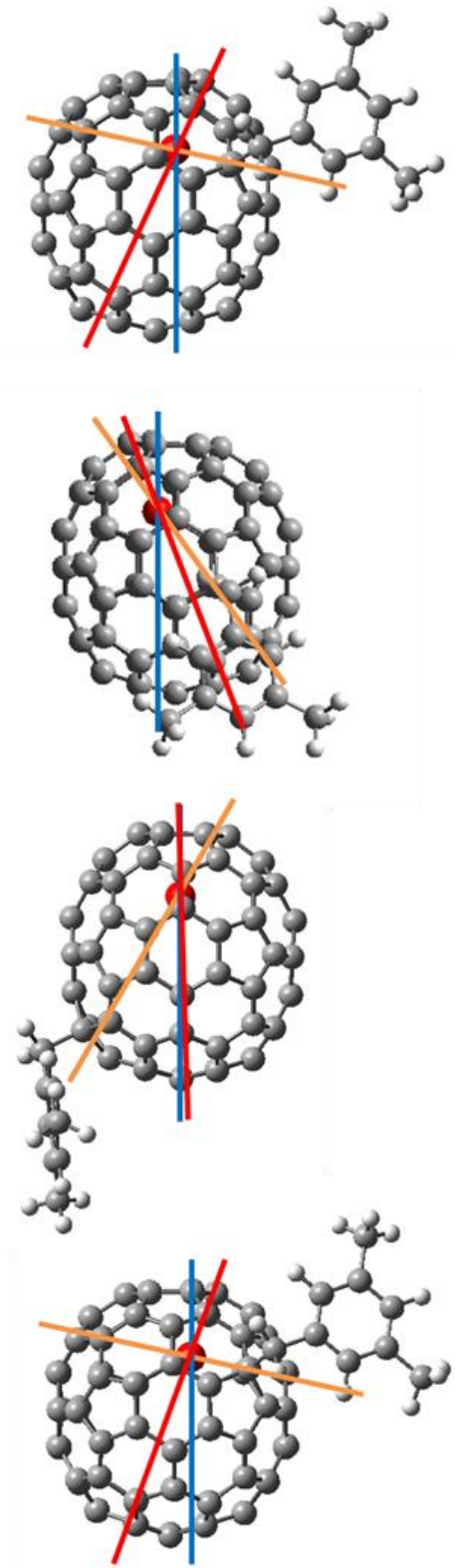

Figure S7. DFT optimized structures of $\mathrm{Ce} @ \mathrm{C}_{82}\left(\mathrm{CH}_{2}-3,5-\mathrm{C}_{6} \mathrm{H}_{3} \mathrm{Me}_{2}\right)$ with addition position of (a) $\mathrm{C} 9$, (b) C10, (c) C14 and (d) C18, computed at the UB3LYP/3-21G $\sim$ SDD level, and (e) single crystal structure of 1d, showing 3 possible definitions of the axis. Blue line: the axis parallel to the original $C_{2 v}$ axis of the pristine Ce@ $\mathrm{C}_{82}$. Red line: the axis along with the direction of local electric field predicted by the DFT calculation. Yellow line: the axis connecting the $\mathrm{Ce}$ atom and the addition position. 


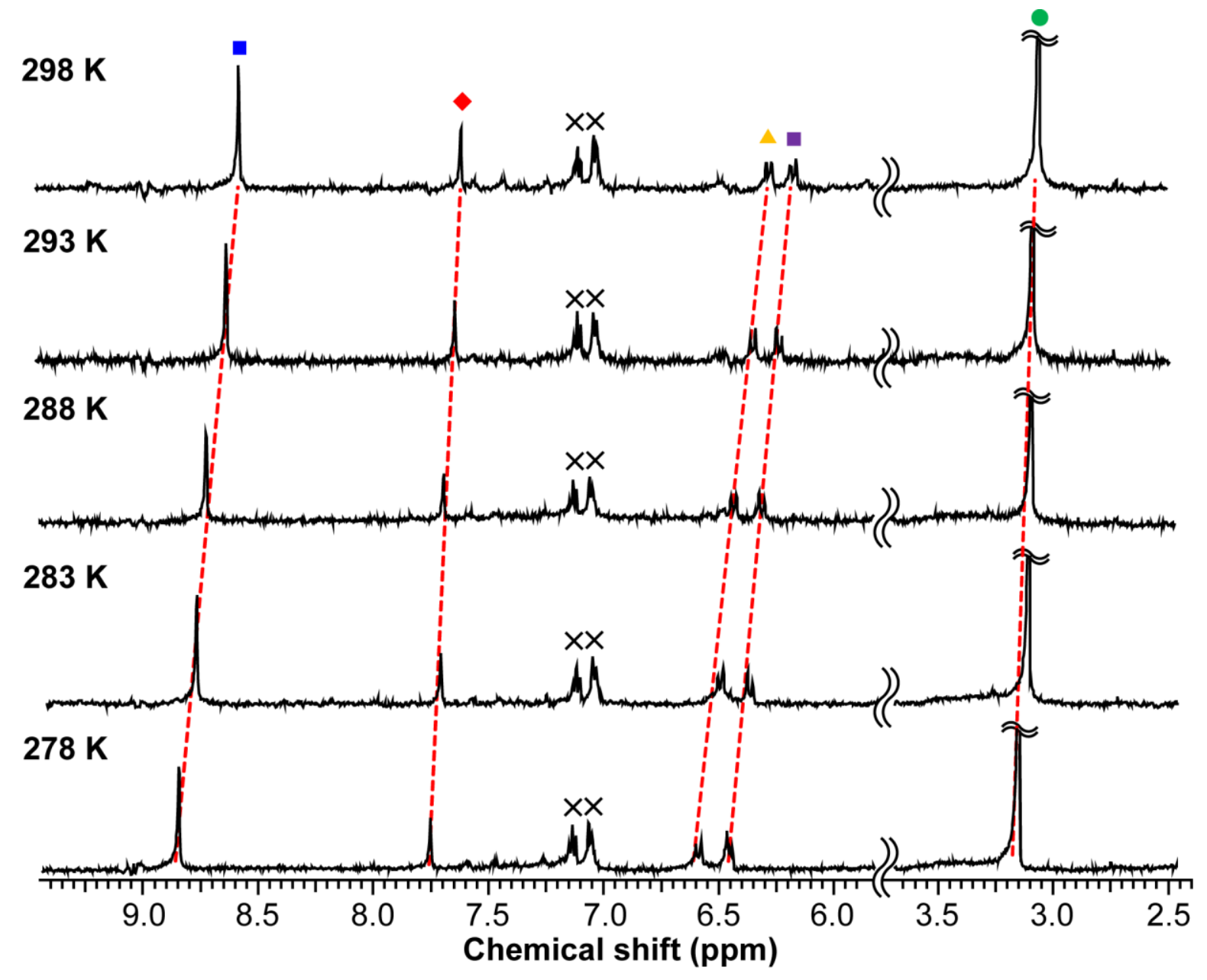

Figure S8. ${ }^{1} \mathrm{H}$ NMR spectra of anionic $1 \mathrm{a}$ at $500 \mathrm{MHz}$ in $\mathrm{CS}_{2} / \mathrm{CD}_{2} \mathrm{Cl}_{2}=3 / 1(\mathrm{v} / \mathrm{v})$ at various temperatures. $\mathrm{X}$ marks indicate temperature-independent signals of toluene for highlighting the other TD signals. 


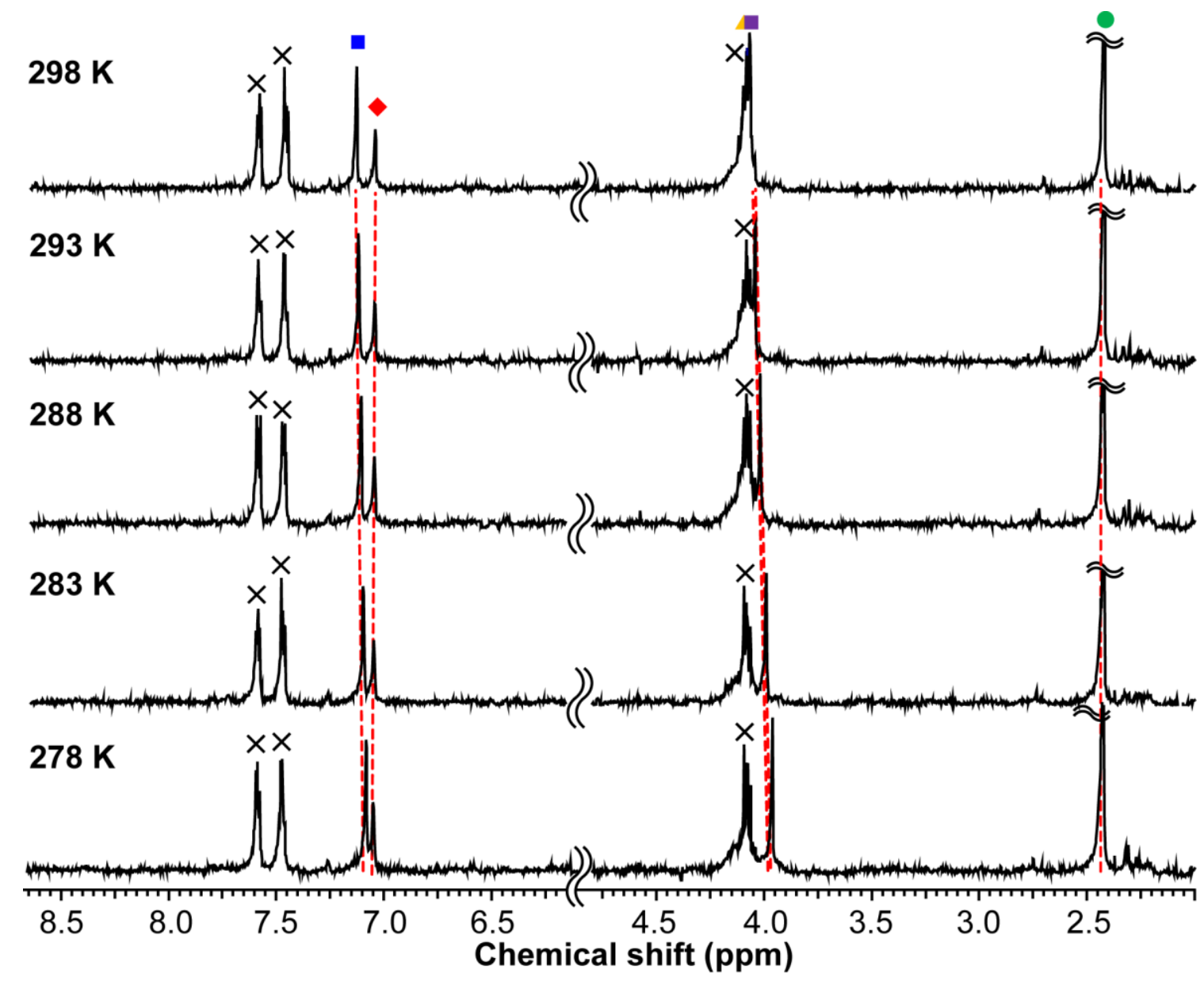

Figure S9. ${ }^{1} \mathrm{H}$ NMR spectra of anionic $1 \mathrm{~b}$ at $500 \mathrm{MHz}$ in $\mathrm{CS}_{2} / \mathrm{CD}_{2} \mathrm{Cl}_{2}=3 / 1(\mathrm{v} / \mathrm{v})$ at various temperatures. Xmarks indicate temperature-independent signals of dibutyl phthalate for highlighting the other TD signals. 


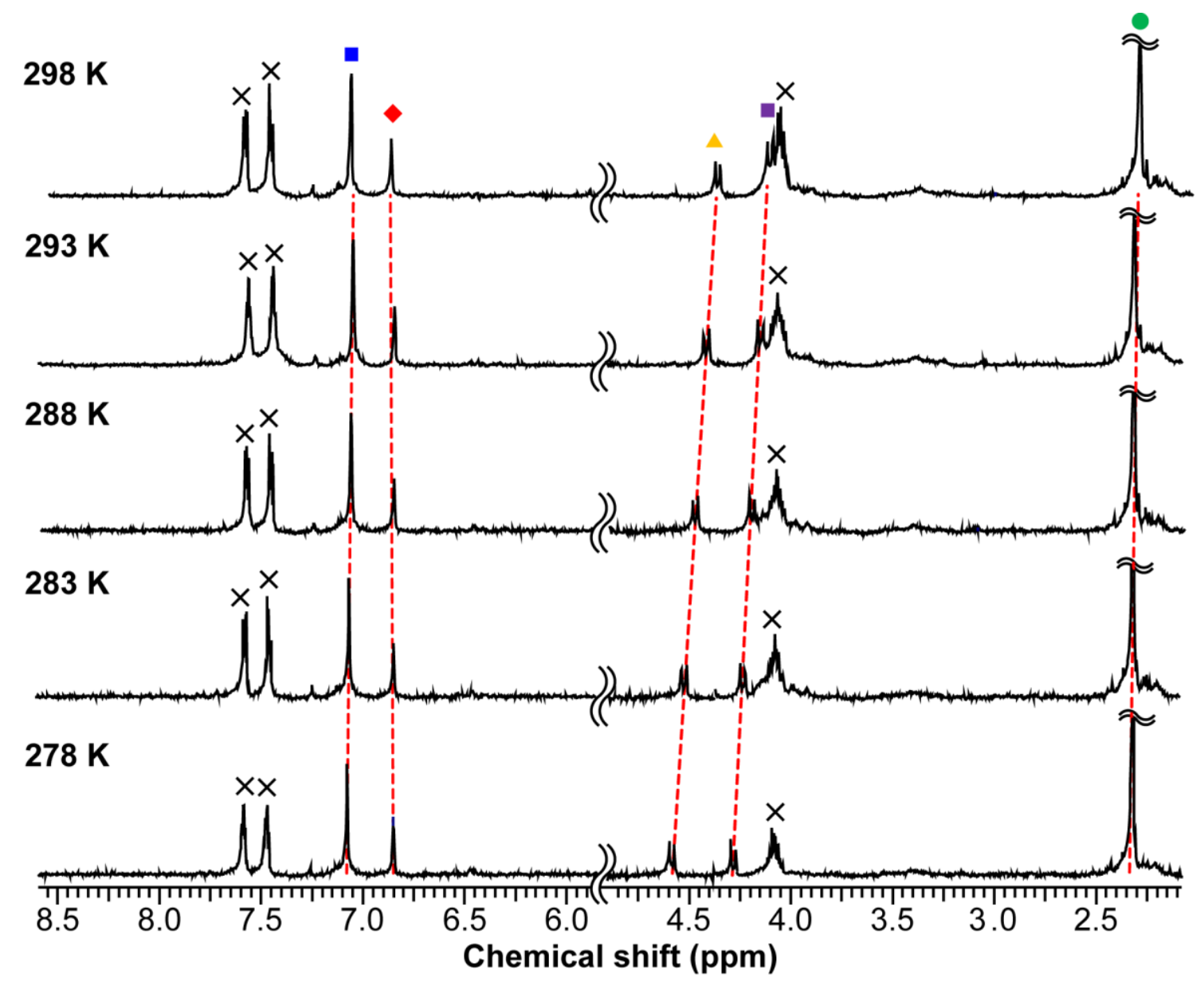

Figure S10. ${ }^{1} \mathrm{H}$ NMR spectra of anionic $1 \mathrm{c}$ at $500 \mathrm{MHz}$ in $\mathrm{CS}_{2} / \mathrm{CD}_{2} \mathrm{Cl}_{2}=3 / 1(\mathrm{v} / \mathrm{v})$ at various temperatures. Xmarks indicate temperature-independent signals of dibutyl phthalate for highlighting the other TD signals. 


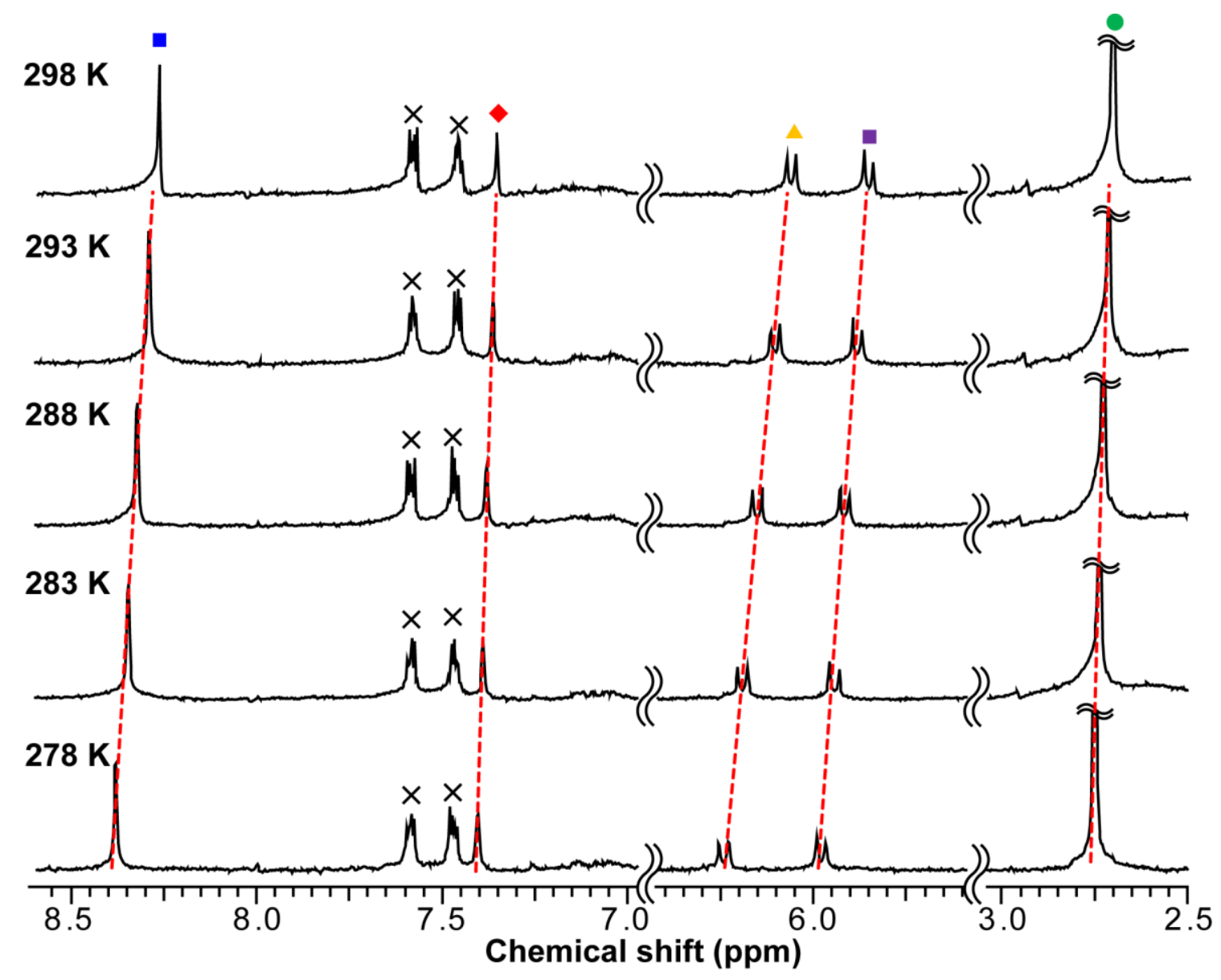

Figure S11. ${ }^{1} \mathrm{H}$ NMR spectra of anionic $1 d$ at $500 \mathrm{MHz}$ in $\mathrm{CS}_{2} / \mathrm{CD}_{2} \mathrm{Cl}_{2}=3 / 1(\mathrm{v} / \mathrm{v})$ at various temperatures. Xmarks indicate temperature-independent signals of dibutyl phthalate for highlighting the other TD signals. 
a

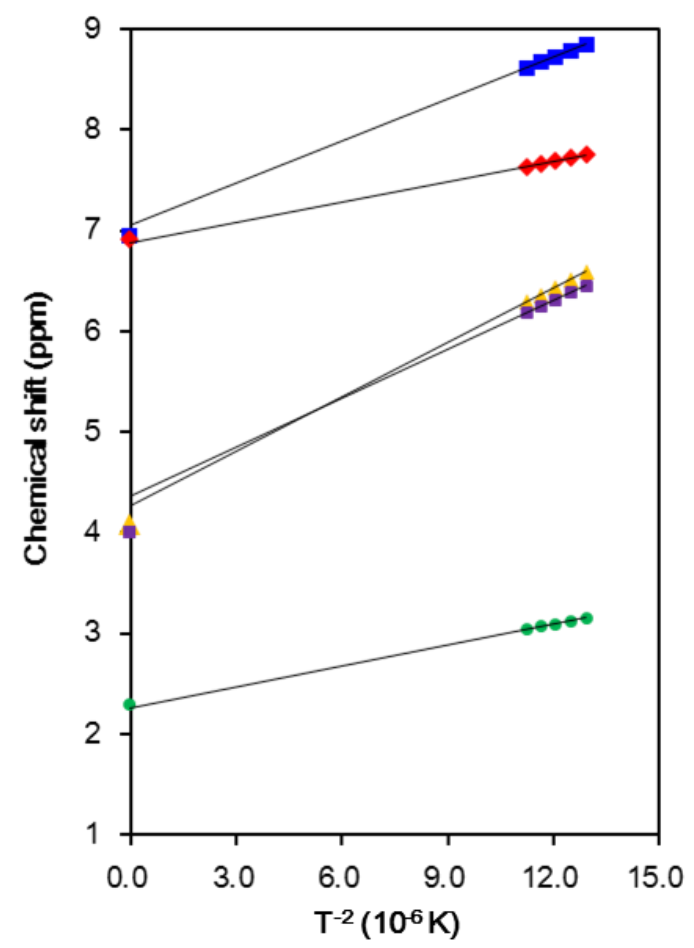

C

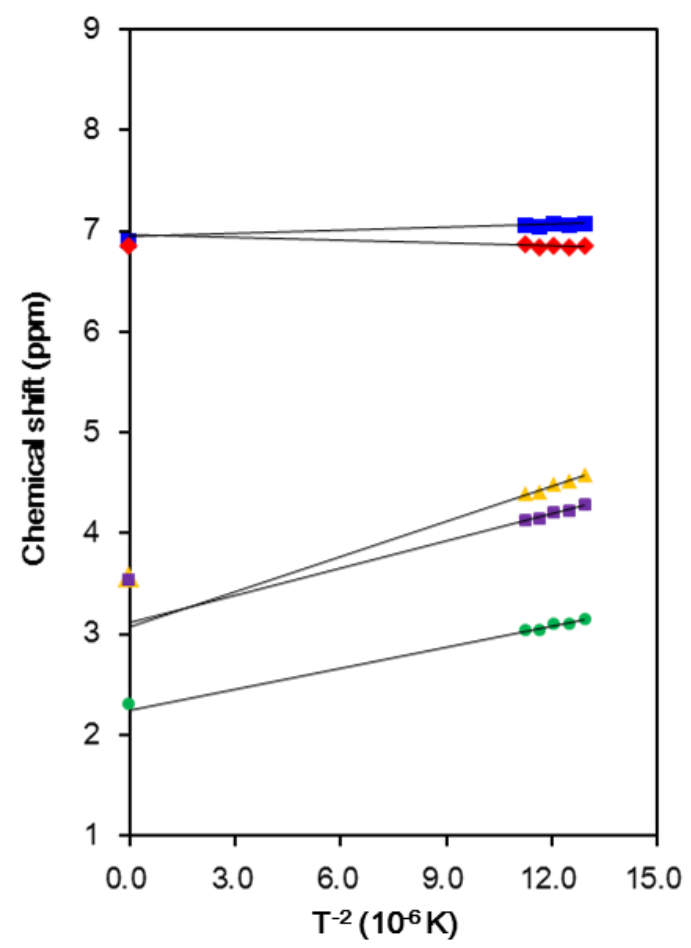

b

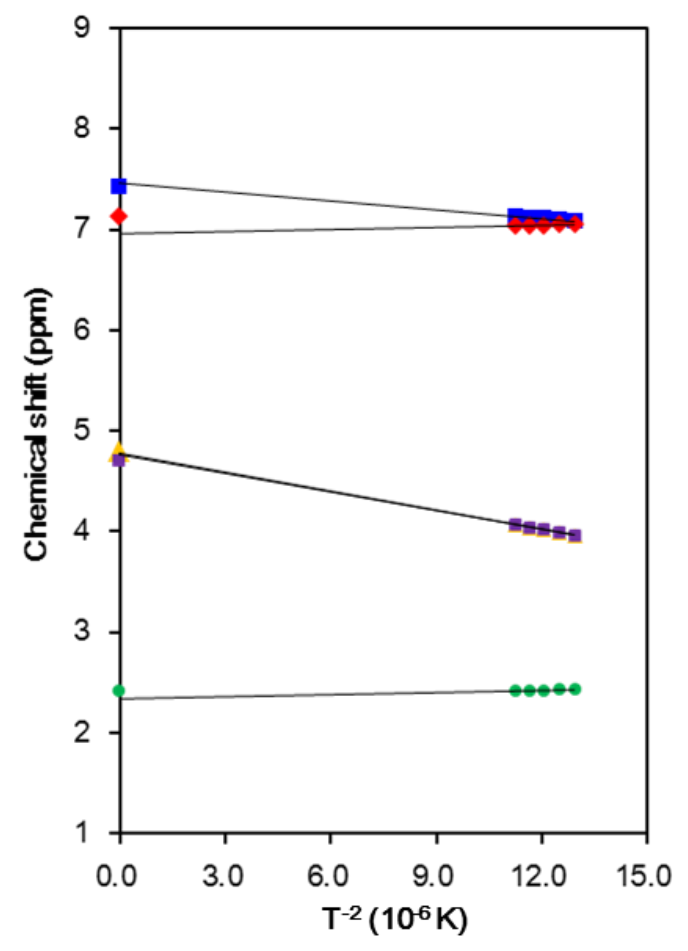

d

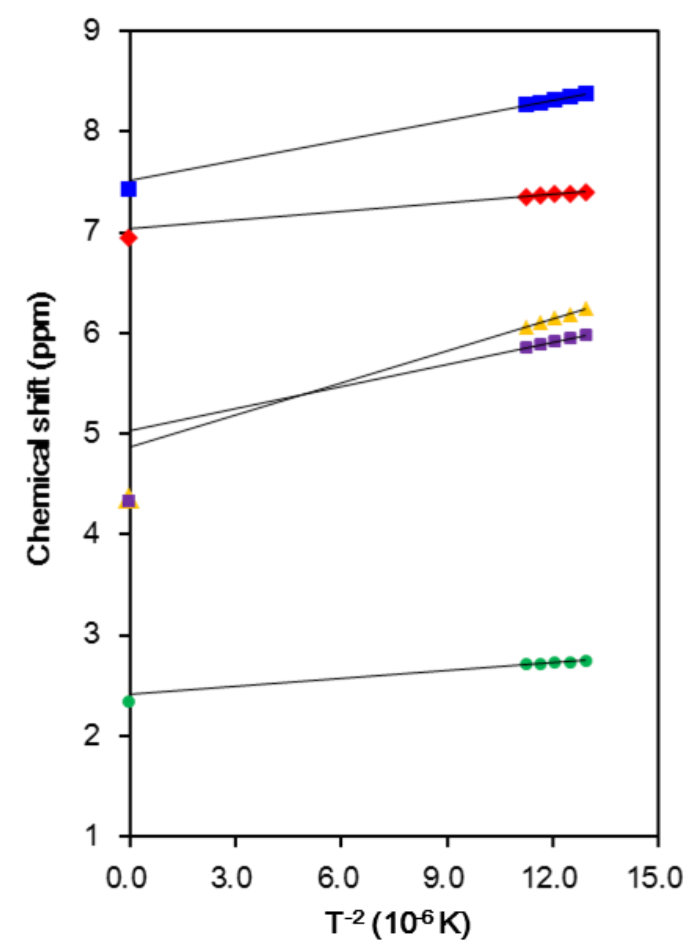

Figure S12. Linear fitting plots of the ${ }^{1} \mathrm{H}-\mathrm{NMR}$ measurements of (a) $1 \mathbf{a},(\mathbf{b}) \mathbf{1 b},(\mathbf{c}) \mathbf{1 c}$ and (d) $1 \mathrm{~d}$, demonstrating the dependency of the chemical shifts on $T^{-2}$. The values at $T^{-2}=0$ are plotted by the observed chemical shifts of corresponding 2 recorded at r.t., which are theoretically expected to be the same to the shifts of $\mathbf{1}$ at $T^{-2}=0$. The colored symbols in the parentheses correspond to the symbols in Figures S7 and S17. 

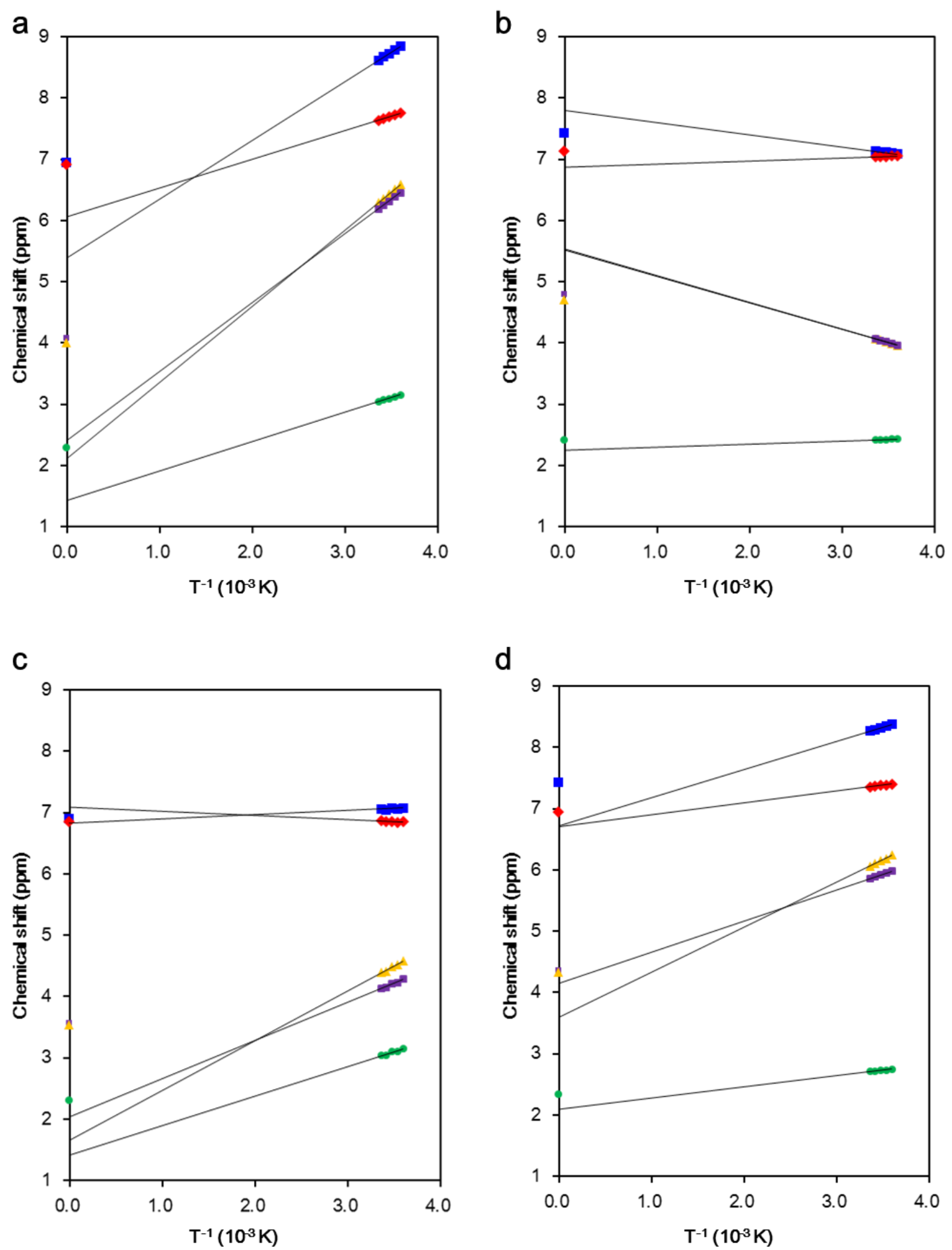

Figure S13. Linear fitting plots of the ${ }^{1} \mathrm{H}-\mathrm{NMR}$ measurements of (a) 1a, (b) $1 \mathbf{b}$, (c) $1 \mathrm{c}$ and (d) 1 d, demonstrating the dependency of the chemical shifts on $T^{-1}$. The values at $T^{-1}=0$ are plotted by the observed chemical shifts of corresponding $\mathbf{2}$ recorded at r.t., which are theoretically expected to be the same to the shifts of 1 at $T^{-1}=0$. The colored symbols in the parentheses correspond to the symbols in Figures S7 and S17. 


\section{Front view}

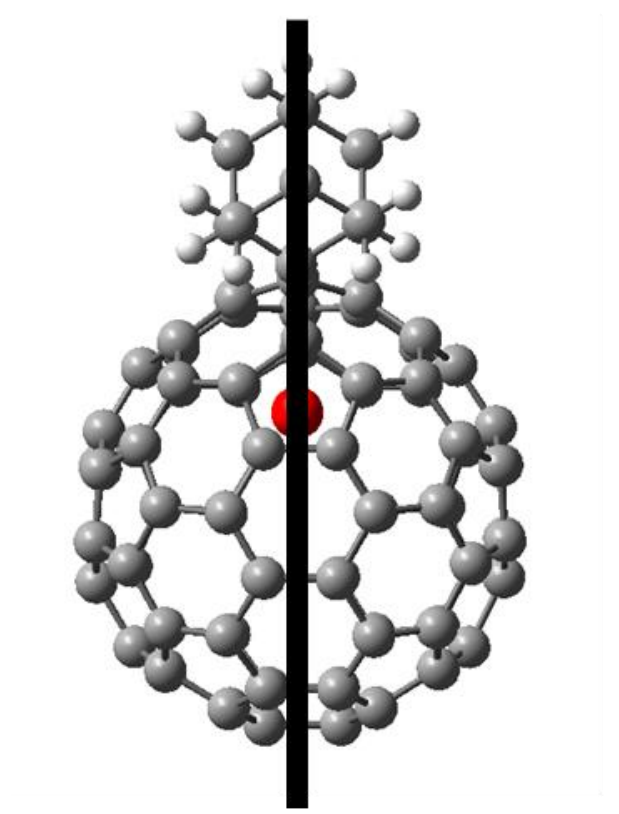

\section{Side view}

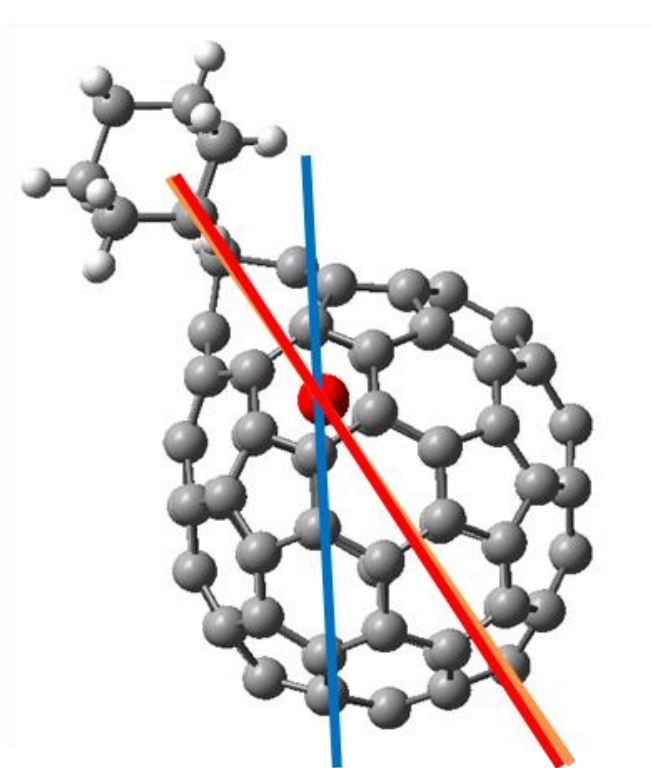

Figure S14. Single crystal structure of $\mathrm{Ce} @ \mathrm{C}_{82} \mathrm{Ad}-\mathrm{B}$ obtained by the data from Ref. S13, showing 3 possible definitions of the axis. Blue line: the axis parallel to the original $C_{2 v}$ axis of the pristine $\mathrm{Ce}_{0} \mathrm{C}_{82}$. Red line: the axis along with the direction of local electric field predicted by the DFT calculation. Yellow line: the axis connecting the $\mathrm{Ce}$ atom and the addition position. In the front view, the black line indicates the three axes which are overlapped each other.

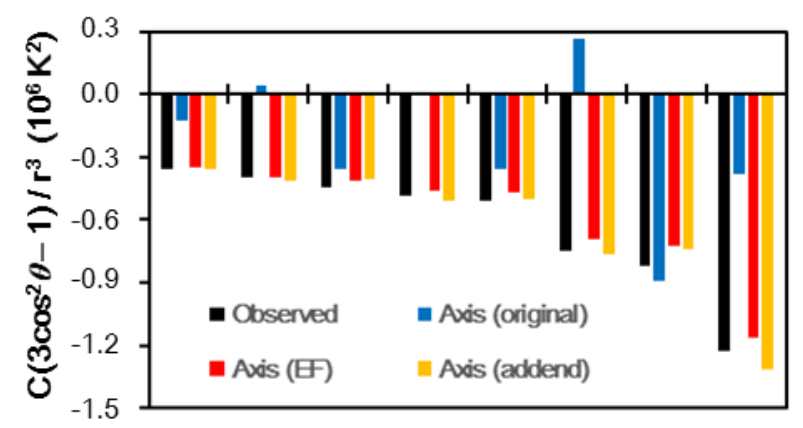

Figure S15. Temperature dependence of ${ }^{1} \mathrm{H}-\mathrm{NMR}$ signals to $T^{-2}$ obtained for $\mathrm{Ce}_{0} @ \mathrm{C}_{82} \mathrm{Ad}-\mathrm{B}$ in the descending order of the values, based on its crystal structure. ${ }^{\mathrm{S13}}$ Black bars indicate the observed values, and values calculated based on each of the axes in Figure S14 are colored accordingly. 


\section{Front view}

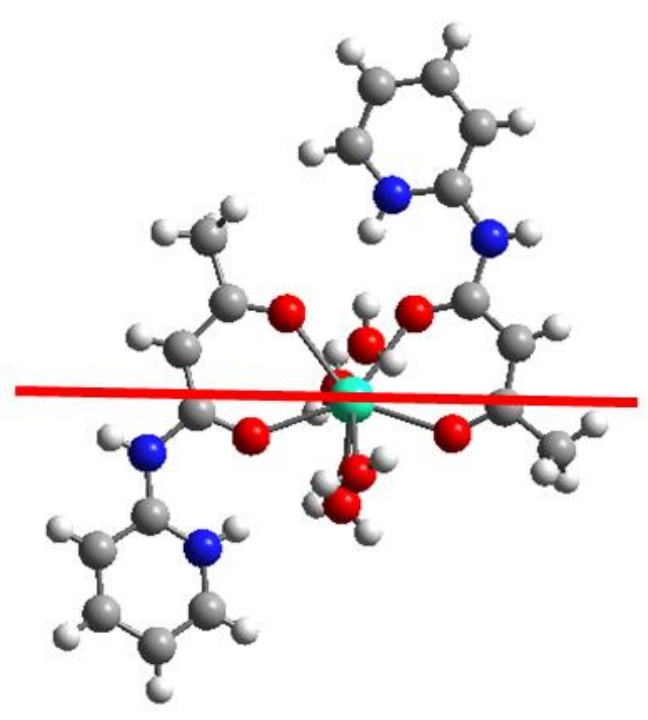

Side view

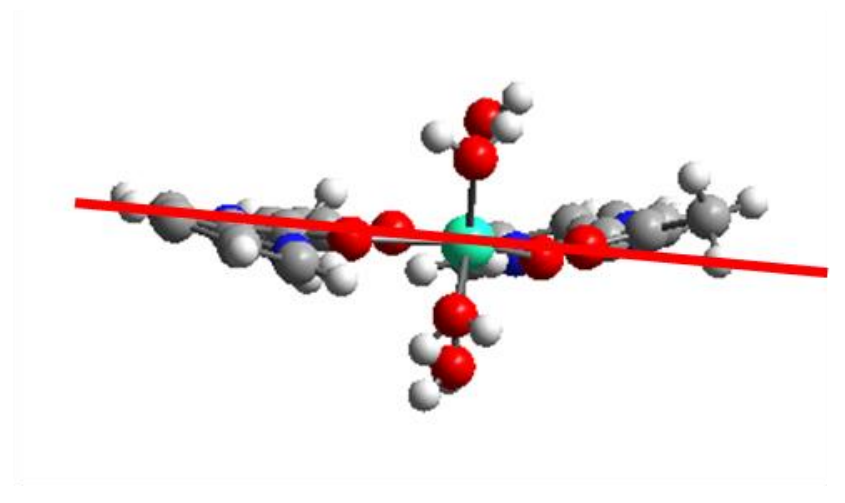

Figure S16. Single crystal structures of $\left[\mathrm{Dy}\left(\mathrm{paaH}^{*}\right)_{2}\left(\mathrm{H}_{2} \mathrm{O}\right)_{4}\right]_{3}$ obtained from Ref. S14. Spin multiplicity of the Dy atom is doublet. Red line: the axis along with the direction of local electric field predicted by the DFT calculations at the B3LYP/6-31G* [C, N, O and H], SDD [Dy] level. 
a

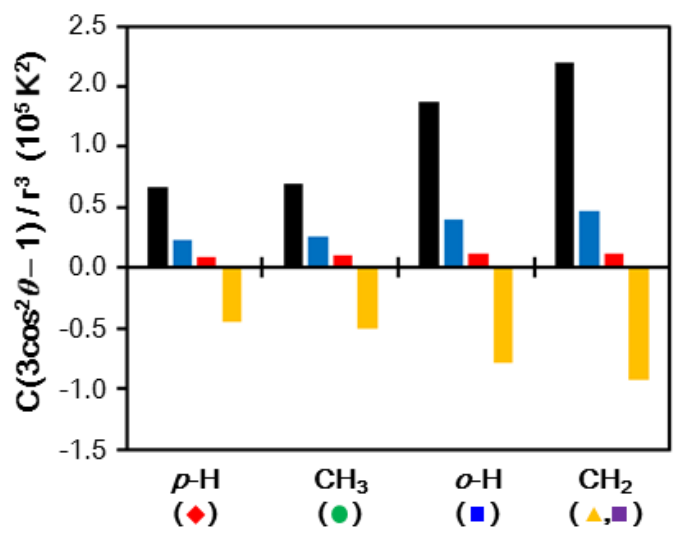

C

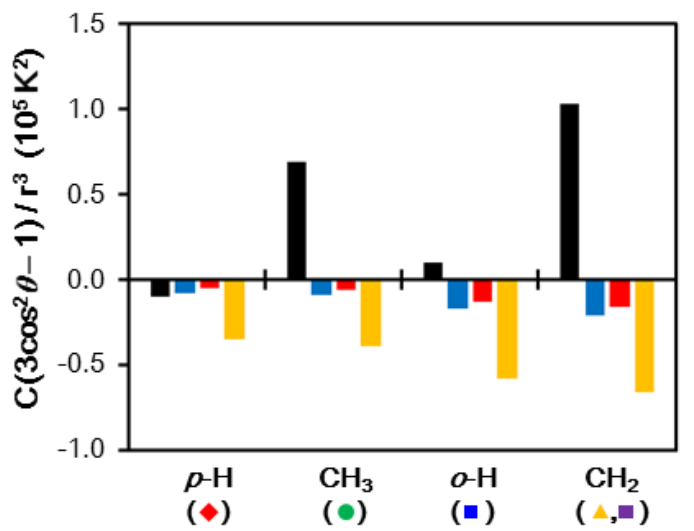

b

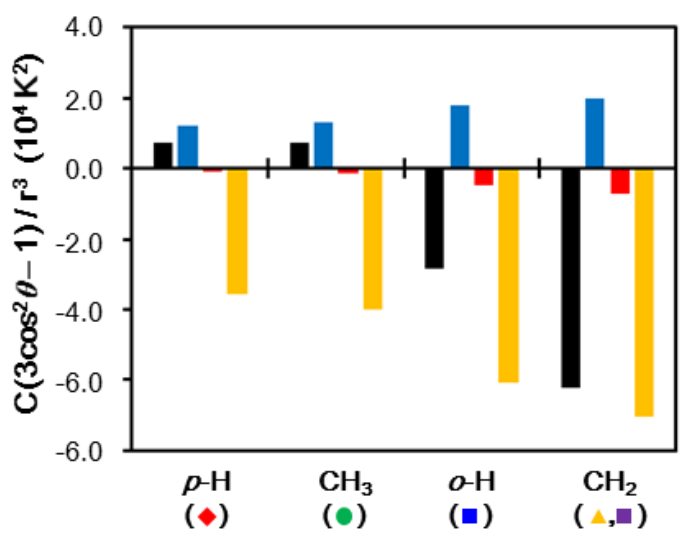

d

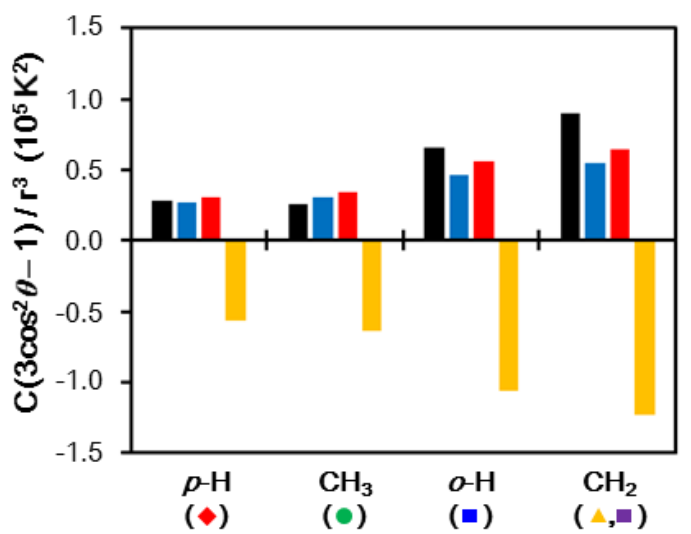

Figure S17. Temperature dependence of ${ }^{1} \mathrm{H}-\mathrm{NMR}$ signals to $T^{-2}$ obtained for (a) $\mathbf{1 a},(\mathbf{b}) \mathbf{1 b},(\mathbf{c}) \mathbf{1 c}$ and (d) $\mathbf{1 d}$. Black bars indicate the observed values, and values calculated based on each of the axes in Figure S7 are colored accordingly.

Table S1. Comparison of the molecular structure of $\mathbf{1 d}$ obtained by the single crystal structure (SCXRD) and DFT optimized structures by various computing methods.

\begin{tabular}{cccccc}
\hline Method & Level & $\begin{array}{c}\text { Averaged distance } \\
\text { between Ce atom and } \\
\text { the six nearest carbon } \\
\text { atoms forming } \\
\text { hexagon }(\AA)\end{array}$ & $\begin{array}{c}\Delta \text { DFT- } \\
\text { ScXRD }(\AA)\end{array}$ & $\begin{array}{c}\text { Averaged distance } \\
\text { between Ce atom and } \\
\text { the } p \text {-H of the mesitylene } \\
\text { moiety }(\AA)\end{array}$ & $\begin{array}{c}\Delta \text { DFT-SCXRD } \\
(\AA)\end{array}$ \\
\hline SCXRD & 2.666 & 8.658 & \\
DFT & UB3LYP/3-21G & 2.718 & 0.051 & 8.610 & -0.048 \\
DFT & UB3LYP/6-31G* & 2.753 & 0.087 & 8.841 & 0.183 \\
DFT & UB3LYP-D3/3-21G & 2.754 & 0.088 & 8.030 & -0.628 \\
DFT & UB3LYP-D3/6-31G* & 2.743 & 0.077 & 8.370 & -0.288 \\
DFT & UMO66-2X/3-21G & 2.782 & 0.116 & 7.812 & -0.846 \\
DFT & UM06-2X/6-31G* & 2.762 & 0.095 & 8.229 & -0.429 \\
\hline
\end{tabular}


Table S2. Statistical analysis of the observed paramagnetic shifts in the ${ }^{1} \mathrm{H}-\mathrm{NMR}$ signals of compound 1a, 1b, and 1c in Figure S17, and the corresponding values for different candidates as the addend location.

\begin{tabular}{|c|c|c|c|c|c|}
\hline Compound & $\begin{array}{l}\text { Addition } \\
\text { position }\end{array}$ & $\begin{array}{l}\text { Axis } \\
\text { system }\end{array}$ & $\begin{array}{l}\text { Pearson product-moment } \\
\text { correlation coefficient }\end{array}$ & $\begin{array}{c}p \text { value for } t \\
\text { test }\end{array}$ & $\mathrm{R}^{2}$ \\
\hline \multirow[t]{9}{*}{$1 a$} & C09 & original & 0.99 & 0.07 & 0.98 \\
\hline & & $\mathrm{EF}$ & 0.98 & 0.07 & 0.96 \\
\hline & & addend & -0.99 & 0.05 & 0.98 \\
\hline & C14 & original & 0.99 & 0.07 & 0.98 \\
\hline & & $\mathrm{EF}$ & -0.99 & 0.06 & 0.99 \\
\hline & & addend & -0.99 & 0.05 & 0.98 \\
\hline & $\mathrm{C} 18$ & original & -0.99 & 0.06 & 0.99 \\
\hline & & $\mathrm{EF}$ & -0.99 & 0.06 & 0.99 \\
\hline & & addend & -0.99 & 0.05 & 0.98 \\
\hline \multirow[t]{9}{*}{$1 b$} & C09 & original & 0.99 & 0.18 & 0.98 \\
\hline & & $\mathrm{EF}$ & -0.97 & 0.35 & 0.95 \\
\hline & & addend & 0.99 & 0.00 & 0.98 \\
\hline & C14 & original & -0.99 & 0.30 & 0.97 \\
\hline & & $\mathrm{EF}$ & 0.99 & 0.84 & 0.99 \\
\hline & & addend & 0.99 & 0.01 & 0.98 \\
\hline & $\mathrm{C} 18$ & original & 0.99 & 0.55 & 0.98 \\
\hline & & $\mathrm{EF}$ & 0.99 & 0.77 & 0.98 \\
\hline & & addend & 0.99 & 0.02 & 0.98 \\
\hline \multirow[t]{9}{*}{$1 c$} & C09 & original & -0.12 & 0.81 & 0.01 \\
\hline & & $\mathrm{EF}$ & -0.05 & 0.65 & 0.00 \\
\hline & & addend & 0.12 & 0.08 & 0.02 \\
\hline & C14 & original & -0.11 & 0.76 & 0.01 \\
\hline & & $\mathrm{EF}$ & 0.16 & 0.39 & 0.03 \\
\hline & & addend & 0.12 & 0.10 & 0.02 \\
\hline & $\mathrm{C} 18$ & original & 0.14 & 0.28 & 0.02 \\
\hline & & $\mathrm{EF}$ & 0.15 & 0.32 & 0.02 \\
\hline & & addend & 0.12 & 0.11 & 0.02 \\
\hline
\end{tabular}


Table S3. Cartesian coordinates $(\AA)$ of $\mathrm{Ce} @ \mathrm{C}_{82}\left(\mathrm{CH}_{2}-3,5-\mathrm{C}_{6} \mathrm{H}_{3} \mathrm{Me}_{2}\right)$ with addition position of $\mathrm{C} 2, \mathrm{C} 3, \mathrm{C} 9, \mathrm{C} 10$, C14, C18 and C19, computed at the UB3LYP/3-21G SDD level.

\section{C2:}

$\mathrm{Ce} \quad-1.12134972-0.49268938 \quad 0.18874158$

C $\quad-0.79619814 \quad-3.73744066 \quad 0.63649806$

C $\quad-0.71203636-1.04270815 \quad 3.72291971$

C $\quad 0.42756522 \quad-1.93444954 \quad 3.60307675$

C $\quad 0.38531761 \quad-3.03296990 \quad 2.70856897$

C $\quad-0.82576281 \quad-3.22470980 \quad 1.96308545$

C $\quad-1.97595172 \quad-2.37467713 \quad 2.08929519$

$\begin{array}{llll}\text { C } & -1.88335212 & -1.22678044 & 2.95574891\end{array}$

$\begin{array}{llll}\text { C } & 1.62443360 & -1.16958324 & 3.76728939\end{array}$

$\begin{array}{llll}\text { C } & 1.60044786 & -3.45481332 & 2.13033464\end{array}$

$\begin{array}{llll}\text { C } & 0.44061565 & -4.10369302 & 0.00885545\end{array}$

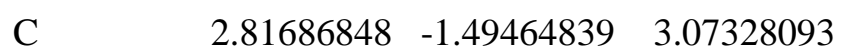

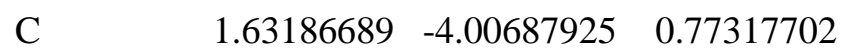

$\begin{array}{lllll}\text { C } & 2.87002314 & -3.63948366 & 0.16477708\end{array}$

$\begin{array}{llll}\text { C } & 3.62095338 & -2.88324041 & 1.15787981\end{array}$

C $\quad \begin{array}{llll}2.95233038 & -3.30742221 & -1.21642243\end{array}$

$\begin{array}{llll}\text { C } & 2.81414884 & -2.72382746 & 2.34914396\end{array}$

$\begin{array}{lllll}\text { C } & & 4.47525697 & -1.88721159 & 0.77724978\end{array}$

$\begin{array}{lllll}\text { C } & & 3.87279680 & -2.23199201 & -1.63076758\end{array}$

C $\quad 4.64273586 \quad-1.56317233 \quad-0.63662646$

$\begin{array}{llll}\text { C } & 3.70066912 & -0.40178621 & 2.64191382\end{array}$

$\begin{array}{lllll}\text { C } & & 4.57226751 & -0.66362034 & 1.55772162\end{array}$

$\begin{array}{llll}\text { C } & 4.94460979 & -0.16922284 & -0.72635762\end{array}$

$\begin{array}{lllll}\text { C } & 4.49155418 & 0.62778959 & -1.80899766\end{array}$

$\begin{array}{llll}\text { C } & 4.96075984 & 0.36911677 & 0.63445962\end{array}$

$\begin{array}{llll}\text { C } & -2.40493652 & 2.08878164 & 1.69806652\end{array}$ 


\begin{tabular}{|c|c|c|c|}
\hline $\mathrm{C}$ & -3.23909711 & -0.86435158 & -1.06861414 \\
\hline $\mathrm{C}$ & -0.18491146 & 0.27952806 & 4.00866721 \\
\hline $\mathrm{C}$ & -2.41372117 & -1.69966222 & -1.92393901 \\
\hline $\mathrm{C}$ & -3.02279091 & 0.49650773 & -1.52385110 \\
\hline $\mathrm{C}$ & -0.85010405 & 1.43378427 & 3.52488652 \\
\hline $\mathrm{C}$ & -1.74667976 & -2.89095844 & -1.47466762 \\
\hline $\mathrm{C}$ & -3.00233330 & 1.63587217 & -0.64872987 \\
\hline $\mathrm{C}$ & -2.05662680 & 1.22750099 & 2.77493709 \\
\hline $\mathrm{C}$ & -1.92135215 & -3.19517484 & -0.07443350 \\
\hline $\mathrm{C}$ & -3.17711591 & 1.33112614 & 0.75214015 \\
\hline $\mathrm{C}$ & -2.61760298 & -0.06794629 & 2.51076231 \\
\hline $\mathrm{C}$ & -2.68944514 & -2.35944269 & 0.82353458 \\
\hline $\mathrm{C}$ & -3.34755833 & -0.01625629 & 1.25294887 \\
\hline $\mathrm{C}$ & -3.70323605 & -1.25668943 & 0.37431483 \\
\hline $\mathrm{C}$ & 1.24344870 & 0.20843009 & 4.01997282 \\
\hline $\mathrm{C}$ & -1.71978273 & -0.86355282 & -2.86906387 \\
\hline $\mathrm{C}$ & -2.09219258 & 0.48248065 & -2.62317619 \\
\hline $\mathrm{C}$ & -0.06524193 & 2.56782062 & 3.22979681 \\
\hline $\mathrm{C}$ & -0.55420837 & -3.27086367 & -2.11612762 \\
\hline $\mathrm{C}$ & -2.21732724 & 2.74353646 & -1.01724299 \\
\hline $\mathrm{C}$ & -1.58000502 & 3.20653600 & 1.34259908 \\
\hline $\mathrm{C}$ & 2.04672577 & 1.29169395 & 3.58363865 \\
\hline $\mathrm{C}$ & -0.47618879 & -1.19863870 & -3.48495197 \\
\hline $\mathrm{C}$ & -1.24239095 & 1.57295604 & -2.97940925 \\
\hline $\mathrm{C}$ & -0.43654037 & 3.47306922 & 2.13835059 \\
\hline $\mathrm{C}$ & 0.54248882 & -3.91700073 & -1.39033558 \\
\hline $\mathrm{C}$ & -1.52783457 & 3.56968309 & -0.02341282 \\
\hline $\mathrm{C}$ & 0.75844263 & 3.99734175 & 1.56011290 \\
\hline
\end{tabular}




\begin{tabular}{|c|c|c|c|}
\hline $\mathrm{C}$ & 1.78224235 & -3.54461798 & -1.99487670 \\
\hline $\mathrm{C}$ & -0.32861424 & 4.08851092 & -0.60085129 \\
\hline $\mathrm{C}$ & 1.87320936 & 3.43685817 & 2.31296814 \\
\hline $\mathrm{C}$ & 1.46450115 & -2.69309639 & -3.13109695 \\
\hline $\mathrm{C}$ & -0.28138793 & 3.62146720 & -1.97773301 \\
\hline $\mathrm{C}$ & 0.86899541 & 4.22695752 & 0.15966205 \\
\hline $\mathrm{C}$ & 1.36533534 & 2.51426014 & 3.30589455 \\
\hline $\mathrm{C}$ & 0.04120666 & -2.47378624 & -3.17009396 \\
\hline $\mathrm{C}$ & -1.40305768 & 2.74938275 & -2.21639245 \\
\hline $\mathrm{C}$ & 3.07068423 & 3.18789158 & 1.70425843 \\
\hline $\mathrm{C}$ & 2.32158416 & -1.69597572 & -3.52530734 \\
\hline $\mathrm{C}$ & 0.91852045 & 3.37886041 & -2.59827109 \\
\hline $\mathrm{C}$ & 2.16080792 & 3.95818364 & -0.50001427 \\
\hline $\mathrm{C}$ & 3.24771119 & 3.47732803 & 0.28438841 \\
\hline $\mathrm{C}$ & 3.56590536 & -1.46807479 & -2.79037653 \\
\hline $\mathrm{C}$ & 2.17194490 & 3.57502300 & -1.86944063 \\
\hline $\mathrm{C}$ & 3.31389134 & 0.99714815 & 2.89808080 \\
\hline $\mathrm{C}$ & 0.42357477 & -0.11473033 & -3.87913859 \\
\hline $\mathrm{C}$ & 0.03764320 & 1.28120470 & -3.62451455 \\
\hline $\mathrm{C}$ & 3.83539878 & 1.99831515 & 2.04427012 \\
\hline $\mathrm{C}$ & 1.80426315 & -0.42414330 & -3.97369898 \\
\hline $\mathrm{C}$ & 1.06542211 & 2.24878377 & -3.48515630 \\
\hline $\mathrm{C}$ & 4.19377292 & 2.53909377 & -0.23125666 \\
\hline $\mathrm{C}$ & 3.87021955 & -0.07439480 & -2.87653309 \\
\hline $\mathrm{C}$ & 3.12119411 & 2.63707798 & -2.38148842 \\
\hline $\mathrm{C}$ & 4.10327426 & 2.03134835 & -1.55260852 \\
\hline $\mathrm{C}$ & 4.60064756 & 1.66775286 & 0.87165629 \\
\hline $\mathrm{C}$ & 2.81294328 & 0.56068914 & -3.66014306 \\
\hline
\end{tabular}




\begin{tabular}{|c|c|c|c|}
\hline $\mathrm{C}$ & 2.45450774 & 1.85882467 & -3.42356076 \\
\hline $\mathrm{C}$ & -5.19937143 & -1.73022940 & 0.48290807 \\
\hline $\mathrm{H}$ & -5.37730859 & -1.99069538 & 1.53201022 \\
\hline $\mathrm{H}$ & -5.28769622 & -2.63928545 & -0.12225472 \\
\hline $\mathrm{C}$ & -6.17684774 & -0.67594378 & 0.01303229 \\
\hline $\mathrm{C}$ & -6.69746766 & 0.26294705 & 0.91305303 \\
\hline $\mathrm{C}$ & -7.58611142 & 1.25477834 & 0.48375160 \\
\hline $\mathrm{C}$ & -7.94988887 & 1.29536698 & -0.86830692 \\
\hline $\mathrm{C}$ & -7.44179817 & 0.37015996 & -1.78762388 \\
\hline $\mathrm{C}$ & -6.55580316 & -0.61407609 & -1.33347664 \\
\hline $\mathrm{H}$ & -6.41571893 & 0.21452892 & 1.96004563 \\
\hline $\mathrm{H}$ & -8.64615225 & 2.05610630 & -1.20907501 \\
\hline $\mathrm{H}$ & -6.16482282 & -1.34535170 & -2.03371253 \\
\hline $\mathrm{C}$ & -8.13977894 & 2.27972471 & 1.45917589 \\
\hline $\mathrm{H}$ & -7.64997719 & 3.25132822 & 1.31669679 \\
\hline $\mathrm{H}$ & -9.21610789 & 2.42043511 & 1.31091988 \\
\hline $\mathrm{H}$ & -7.97298740 & 1.96561212 & 2.49401843 \\
\hline $\mathrm{C}$ & -7.83031063 & 0.44705114 & -3.25439028 \\
\hline $\mathrm{H}$ & -8.87711308 & 0.74776038 & -3.36830660 \\
\hline $\mathrm{H}$ & -7.20852953 & 1.18446095 & -3.77829174 \\
\hline $\mathrm{H}$ & -7.69374729 & -0.52029996 & -3.74785018 \\
\hline
\end{tabular}

C3:

$\begin{array}{llll}\text { Ce } & -0.28989184 & -0.48788752 & 1.68362687\end{array}$

$\begin{array}{llll}\text { C } & -0.98848880 & -3.65989499 & 0.33197011\end{array}$

C $\quad-\quad-0.51374521 \quad-1.51611373 \quad 3.90355452$

$\begin{array}{llll}\text { C } & 0.57994913 & -2.35091116 & 3.39976767\end{array}$

C $\quad 0.42917363 \quad-3.32237854 \quad 2.34323453$ 


\begin{tabular}{|c|c|c|c|}
\hline $\mathrm{C}$ & -0.86448344 & -3.39646801 & 1.74365066 \\
\hline $\mathrm{C}$ & -1.93231860 & -2.49921626 & 2.14491893 \\
\hline $\mathrm{C}$ & -1.83384227 & -1.56970040 & 3.24481437 \\
\hline $\mathrm{C}$ & 1.80214967 & -1.59571465 & 3.45348514 \\
\hline $\mathrm{C}$ & 1.55825118 & -3.64182981 & 1.56110640 \\
\hline $\mathrm{C}$ & 0.16439001 & -3.93126938 & -0.48793322 \\
\hline $\mathrm{C}$ & 2.93656003 & -1.83957805 & 2.60355884 \\
\hline $\mathrm{C}$ & 1.43206944 & -3.96349222 & 0.15046255 \\
\hline $\mathrm{C}$ & 2.61972758 & -3.52828820 & -0.53435068 \\
\hline $\mathrm{C}$ & 3.49316531 & -2.94757901 & 0.45994589 \\
\hline $\mathrm{C}$ & 2.55724016 & -2.98573242 & -1.84991799 \\
\hline $\mathrm{C}$ & 2.82055012 & -2.94477851 & 1.73126012 \\
\hline $\mathrm{C}$ & 4.35116811 & -1.91313533 & 0.14467580 \\
\hline $\mathrm{C}$ & 3.46639680 & -1.87430736 & -2.19974309 \\
\hline $\mathrm{C}$ & 4.36822830 & -1.38026834 & -1.21755154 \\
\hline $\mathrm{C}$ & 3.81173779 & -0.72626736 & 2.26652106 \\
\hline $\mathrm{C}$ & 4.57882035 & -0.84316002 & 1.07011281 \\
\hline $\mathrm{C}$ & 4.71686229 & 0.00588908 & -1.13869804 \\
\hline $\mathrm{C}$ & 4.16983712 & 0.96769277 & -2.02972926 \\
\hline $\mathrm{C}$ & 4.89336501 & 0.32532436 & 0.27327409 \\
\hline $\mathrm{C}$ & -2.25256346 & 1.99238505 & 2.46681585 \\
\hline $\mathrm{C}$ & -3.63578079 & -0.49307899 & -0.69503403 \\
\hline $\mathrm{C}$ & 0.09845475 & -0.22273402 & 4.24324486 \\
\hline $\mathrm{C}$ & -2.75729025 & -1.19407580 & -1.74213586 \\
\hline $\mathrm{C}$ & -3.24538496 & 0.97413051 & -0.92398247 \\
\hline $\mathrm{C}$ & -0.56379844 & 1.04331666 & 4.02239364 \\
\hline $\mathrm{C}$ & -2.11466296 & -2.43760425 & -1.51394457 \\
\hline $\mathrm{C}$ & -3.08960927 & 1.91061282 & 0.126856 \\
\hline
\end{tabular}




\begin{tabular}{|c|c|c|c|}
\hline $\mathrm{C}$ & -1.86596170 & 0.97825742 & 3.42196815 \\
\hline $\mathrm{C}$ & -2.11901446 & -2.96015824 & -0.17316797 \\
\hline $\mathrm{C}$ & -3.08405417 & 1.40770721 & 1.47529418 \\
\hline $\mathrm{C}$ & -2.46319465 & -0.28762366 & 3.01003845 \\
\hline $\mathrm{C}$ & -2.68504567 & -2.20224392 & 0.91919241 \\
\hline $\mathrm{C}$ & -3.18161235 & -0.00415509 & 1.76057523 \\
\hline $\mathrm{C}$ & -3.25444020 & -0.94148500 & 0.71457911 \\
\hline $\mathrm{C}$ & 1.51143243 & -0.30068922 & 3.95565636 \\
\hline $\mathrm{C}$ & -2.20279792 & -0.24673526 & -2.60979073 \\
\hline $\mathrm{C}$ & -2.50426999 & 1.09232242 & -2.10452288 \\
\hline $\mathrm{C}$ & 0.24160133 & 2.17478031 & 3.75458808 \\
\hline $\mathrm{C}$ & -1.01438256 & -2.75484106 & -2.34656916 \\
\hline $\mathrm{C}$ & -2.32771673 & 3.07038402 & -0.14832935 \\
\hline $\mathrm{C}$ & -1.42872700 & 3.13745633 & 2.17708428 \\
\hline $\mathrm{C}$ & 2.33739305 & 0.82773221 & 3.61447954 \\
\hline $\mathrm{C}$ & -1.03249564 & -0.49319341 & -3.38560320 \\
\hline $\mathrm{C}$ & -1.63916385 & 2.19314765 & -2.37258015 \\
\hline $\mathrm{C}$ & -0.19378113 & 3.23905447 & 2.86637931 \\
\hline $\mathrm{C}$ & 0.12248597 & -3.51825001 & -1.84188050 \\
\hline C & -1.50782087 & 3.69886215 & 0.88049656 \\
\hline $\mathrm{C}$ & 0.95763057 & 3.82944846 & 2.24061413 \\
\hline $\mathrm{C}$ & 1.30964456 & -3.08486796 & -2.52672020 \\
\hline $\mathrm{C}$ & -0.35623678 & 4.28980720 & 0.25378232 \\
\hline $\mathrm{C}$ & 2.11801932 & 3.14102046 & 2.75717658 \\
\hline $\mathrm{C}$ & 0.90074888 & -2.06411328 & -3.46688430 \\
\hline $\mathrm{C}$ & -0.47916599 & 4.04094074 & -1.16626685 \\
\hline $\mathrm{C}$ & 0.91770706 & 4.26982896 & 0.88487469 \\
\hline $\mathrm{C}$ & 1.68675129 & 2.08125770 & 3.62707157 \\
\hline
\end{tabular}




\begin{tabular}{|c|c|c|c|}
\hline $\mathrm{C}$ & -0.51817055 & -1.81443847 & -3.31107014 \\
\hline $\mathrm{C}$ & -1.65812406 & 3.23506802 & -1.40771398 \\
\hline $\mathrm{C}$ & 3.24851127 & 2.96524935 & 1.98340503 \\
\hline $\mathrm{C}$ & 1.73364614 & -1.02536556 & -3.79536680 \\
\hline $\mathrm{C}$ & 0.62953131 & 3.86130380 & -1.95378545 \\
\hline $\mathrm{C}$ & 2.11985962 & 4.08454527 & 0.04558121 \\
\hline $\mathrm{C}$ & 3.27151852 & 3.47173164 & 0.61137291 \\
\hline $\mathrm{C}$ & 3.05829635 & -0.93442576 & -3.18871122 \\
\hline $\mathrm{C}$ & 1.96164779 & 3.92005381 & -1.36047878 \\
\hline $\mathrm{C}$ & 3.50773014 & 0.61739879 & 2.77369914 \\
\hline $\mathrm{C}$ & -0.14168437 & 0.62502069 & -3.69879274 \\
\hline $\mathrm{C}$ & -0.44571779 & 1.97248682 & -3.19062211 \\
\hline $\mathrm{C}$ & 3.99269742 & 1.74289743 & 2.04404932 \\
\hline $\mathrm{C}$ & 1.21155943 & 0.30845283 & -3.98989876 \\
\hline $\mathrm{C}$ & 0.62955154 & 2.88359068 & -3.01921560 \\
\hline $\mathrm{C}$ & 4.12615688 & 2.61609542 & -0.15470471 \\
\hline $\mathrm{C}$ & 3.40512475 & 0.45067159 & -3.10662785 \\
\hline $\mathrm{C}$ & 2.81484882 & 3.06096280 & -2.12308057 \\
\hline $\mathrm{C}$ & 3.86407452 & 2.32142200 & -1.51978754 \\
\hline $\mathrm{C}$ & 4.61118809 & 1.57575264 & 0.74454218 \\
\hline $\mathrm{C}$ & 2.28306541 & 1.21294224 & -3.65137506 \\
\hline $\mathrm{C}$ & 2.00047576 & 2.46466572 & -3.17964850 \\
\hline $\mathrm{C}$ & -5.18583646 & -0.75744129 & -0.91019747 \\
\hline $\mathrm{H}$ & -5.71035783 & -0.26100631 & -0.08674264 \\
\hline $\mathrm{H}$ & -5.34157892 & -1.83738242 & -0.81676333 \\
\hline $\mathrm{C}$ & -5.70000887 & -0.24974745 & -2.24140994 \\
\hline $\mathrm{C}$ & -6.24796519 & 1.03781885 & -2.33733487 \\
\hline $\mathrm{C}$ & -6.71970041 & 1.52883258 & -3.55665858 \\
\hline
\end{tabular}




$\begin{array}{llll}\mathrm{C} & -6.63259572 & 0.70964495 & -4.69248204 \\ \mathrm{C} & -6.09067286 & -0.57611685 & -4.62268155 \\ \mathrm{C} & -5.62703189 & -1.04789738 & -3.38544583 \\ \mathrm{H} & -6.30820467 & 1.66145741 & -1.45106785 \\ \mathrm{H} & -6.99568667 & 1.08206959 & -5.64564485 \\ \mathrm{H} & -5.20636572 & -2.04629267 & -3.31843782 \\ \mathrm{C} & -7.32271768 & 2.91936125 & -3.66021810 \\ \mathrm{H} & -6.79654663 & 3.51656095 & -4.41409156 \\ \mathrm{H} & -8.37886852 & 2.86454186 & -3.95086457 \\ \mathrm{H} & -7.25911496 & 3.44539755 & -2.70299125 \\ \mathrm{C} & -5.99683603 & -1.45502513 & -5.85838718 \\ \mathrm{H} & -6.42994242 & -0.95275900 & -6.72851820 \\ \mathrm{H} & -4.95084610 & -1.69268812 & -6.08652411 \\ \mathrm{H} & -6.53160923 & -2.40012325 & -5.70695559\end{array}$

C9:

Ce $\quad \begin{array}{llll}-1.60888666 & 0.22362761 & -0.83577396\end{array}$

$\begin{array}{llll}\text { C } & -2.53473466 & 3.11775229 & -0.05441854\end{array}$

$\begin{array}{lllll}\text { C } & -3.08578343 & 0.10957794 & -2.83640223\end{array}$

C $\quad-2.26160546 \quad 1.27175927 \quad-3.19818352$

$\begin{array}{llll}\text { C } & -2.23426499 & 2.48022063 & -2.42034311\end{array}$

C $\quad-3.05469065 \quad 2.48274841 \quad-1.23594504$

C $\quad-3.85627033 \quad 1.32284861 \quad-0.82494826$

C $\quad \begin{array}{llll}-3.91035276 & 0.09932470 & -1.62047707\end{array}$

C $\quad \begin{array}{llll}-1.02094433 & 0.79419883 & -3.75656053\end{array}$

$\begin{array}{llll}\text { C } & -1.03572981 & 3.23188937 & -2.41547367\end{array}$

C $\quad-1.31431736 \quad 3.88025073 \quad-0.03044956$

$\begin{array}{llll}\text { C } & 0.21799669 & 1.51350897 & -3.71423786\end{array}$ 


\begin{tabular}{|c|c|c|c|}
\hline $\mathrm{C}$ & -0.58837591 & 3.96723359 & -1.24300469 \\
\hline $\mathrm{C}$ & 0.84624051 & 4.02270126 & -1.24309848 \\
\hline $\mathrm{C}$ & 1.29528205 & 3.34264938 & -2.43754295 \\
\hline $\mathrm{C}$ & 1.59108760 & 3.93457272 & -0.03005656 \\
\hline $\mathrm{C}$ & 0.15493765 & 2.79465875 & -3.12234173 \\
\hline $\mathrm{C}$ & 2.49072525 & 2.65386384 & -2.45338064 \\
\hline $\mathrm{C}$ & 2.87119932 & 3.20199849 & -0.03916040 \\
\hline $\mathrm{C}$ & 3.32016536 & 2.60921734 & -1.25116082 \\
\hline $\mathrm{C}$ & 1.47003902 & 0.76091952 & -3.71402074 \\
\hline $\mathrm{C}$ & 2.61261836 & 1.40867113 & -3.15833266 \\
\hline $\mathrm{C}$ & 4.03591056 & 1.36926843 & -1.26499863 \\
\hline $\mathrm{C}$ & 4.33337576 & 0.65981010 & -0.07395759 \\
\hline $\mathrm{C}$ & 3.63785598 & 0.65232878 & -2.47581069 \\
\hline $\mathrm{C}$ & -2.67823572 & -3.03705202 & -0.14391054 \\
\hline $\mathrm{C}$ & -2.91687268 & -0.01404011 & 2.57534677 \\
\hline $\mathrm{C}$ & -2.28526787 & -1.06332024 & -3.19884145 \\
\hline $\mathrm{C}$ & -2.15236546 & 1.14811700 & 3.03570920 \\
\hline $\mathrm{C}$ & -2.27272956 & -1.17588798 & 3.00687562 \\
\hline $\mathrm{C}$ & -2.30806756 & -2.29842298 & -2.46863362 \\
\hline $\mathrm{C}$ & -2.16406479 & 2.35226491 & 2.28151435 \\
\hline $\mathrm{C}$ & -2.30512664 & -2.35883522 & 2.22915356 \\
\hline $\mathrm{C}$ & -3.12566921 & -2.31352587 & -1.29703880 \\
\hline $\mathrm{C}$ & -2.96088696 & 2.38112746 & 1.08753584 \\
\hline $\mathrm{C}$ & -3.09392200 & -2.32586659 & 1.03072319 \\
\hline $\mathrm{C}$ & -3.85421655 & -1.12881018 & -0.86000205 \\
\hline $\mathrm{C}$ & -3.74708265 & 1.26829335 & 0.63908271 \\
\hline $\mathrm{C}$ & -3.80001583 & -1.15670639 & 0.61215031 \\
\hline $\mathrm{C}$ & -3.68977522 & 0.03738196 & 1.36393837 \\
\hline
\end{tabular}




\begin{tabular}{|c|c|c|c|}
\hline C & -1.04442835 & -0.62623819 & -3.76643291 \\
\hline $\mathrm{C}$ & -1.00619875 & 0.70076421 & 3.71290417 \\
\hline C & -1.15870226 & -3.11639409 & -2.50833072 \\
\hline $\mathrm{C}$ & -1.01368581 & 3.15869164 & 2.34185511 \\
\hline $\mathrm{C}$ & -1.16254500 & -3.19812936 & 2.25226400 \\
\hline $\mathrm{C}$ & -1.48196254 & -3.81755416 & -0.14516947 \\
\hline $\mathrm{C}$ & 0.16153027 & -1.40171908 & -3.74882151 \\
\hline C & 0.21412368 & 1.41056068 & 3.64147792 \\
\hline $\mathrm{C}$ & 0.17768543 & -1.51197389 & 3.54833606 \\
\hline $\mathrm{C}$ & -0.74744436 & -3.89659137 & -1.35441028 \\
\hline $\mathrm{C}$ & -0.58461541 & 3.93910114 & 1.18219507 \\
\hline $\mathrm{C}$ & -0.75188650 & -3.91617848 & 1.08195549 \\
\hline $\mathrm{C}$ & 0.68902127 & -4.00898818 & -1.35680942 \\
\hline C & 0.84779886 & 3.98994775 & 1.18175764 \\
\hline $\mathrm{C}$ & 0.69281385 & -4.02780391 & 1.07070565 \\
\hline $\mathrm{C}$ & 1.16404989 & -3.30752155 & -2.52223322 \\
\hline $\mathrm{C}$ & 1.29659648 & 3.26973784 & 2.35920971 \\
\hline $\mathrm{C}$ & 1.17019925 & -3.35867536 & 2.25122577 \\
\hline $\mathrm{C}$ & 1.43169606 & -3.96762425 & -0.13940872 \\
\hline $\mathrm{C}$ & 0.04602212 & -2.69723967 & -3.19648600 \\
\hline $\mathrm{C}$ & 0.15437627 & 2.70610159 & 3.04078704 \\
\hline $\mathrm{C}$ & 0.05526122 & -2.76734230 & 2.95155549 \\
\hline $\mathrm{C}$ & 2.39070304 & -2.67089734 & -2.53290928 \\
\hline $\mathrm{C}$ & 2.48404089 & 2.58599363 & 2.35770404 \\
\hline $\mathrm{C}$ & 2.40016503 & -2.74044613 & 2.28563271 \\
\hline $\mathrm{C}$ & 2.74874575 & -3.29419998 & -0.13197660 \\
\hline $\mathrm{C}$ & 3.21991174 & -2.68581743 & -1.32800567 \\
\hline $\mathrm{C}$ & 3.31503563 & 2.57213958 & 1.15939542 \\
\hline
\end{tabular}




\begin{tabular}{|c|c|c|c|}
\hline $\mathrm{C}$ & 3.22695295 & -2.72273168 & 1.08059729 \\
\hline $\mathrm{C}$ & 1.44125702 & -0.70365704 & -3.73560987 \\
\hline $\mathrm{C}$ & 1.48049839 & 0.65578498 & 3.59232760 \\
\hline $\mathrm{C}$ & 1.44342737 & -0.81818514 & 3.55380467 \\
\hline $\mathrm{C}$ & 2.55501321 & -1.41318717 & -3.19557708 \\
\hline $\mathrm{C}$ & 2.60266508 & 1.30933357 & 3.03510656 \\
\hline $\mathrm{C}$ & 2.56245963 & -1.50297974 & 2.98502475 \\
\hline $\mathrm{C}$ & 3.99277369 & -1.48050858 & -1.31088326 \\
\hline $\mathrm{C}$ & 4.02699118 & 1.33206560 & 1.14060350 \\
\hline $\mathrm{C}$ & 3.99779950 & -1.51657415 & 1.09776328 \\
\hline $\mathrm{C}$ & 4.31204826 & -0.81828743 & -0.09566020 \\
\hline $\mathrm{C}$ & 3.61129448 & -0.71302172 & -2.48979767 \\
\hline $\mathrm{C}$ & 3.63378144 & 0.57997425 & 2.32633041 \\
\hline $\mathrm{C}$ & 3.61420486 & -0.78499366 & 2.30268739 \\
\hline $\mathrm{C}$ & -1.10787864 & -0.80135745 & 3.94707809 \\
\hline $\mathrm{C}$ & -1.41647604 & -1.15559854 & 5.46513773 \\
\hline $\mathrm{H}$ & -1.48839900 & -2.24677215 & 5.51958584 \\
\hline $\mathrm{H}$ & -0.54087795 & -0.84164415 & 6.04251329 \\
\hline $\mathrm{C}$ & -2.67227009 & -0.50835662 & 6.01022432 \\
\hline $\mathrm{C}$ & -3.91299444 & -1.14976858 & 5.88271039 \\
\hline $\mathrm{C}$ & -2.60800550 & 0.73046781 & 6.65318516 \\
\hline $\mathrm{C}$ & -5.07766180 & -0.56728617 & 6.38857172 \\
\hline $\mathrm{H}$ & -3.96826777 & -2.11593390 & 5.39144636 \\
\hline $\mathrm{C}$ & -3.76270051 & 1.33625256 & 7.16942032 \\
\hline $\mathrm{H}$ & -1.64969337 & 1.22949228 & 6.76011881 \\
\hline $\mathrm{C}$ & -4.98700303 & 0.67746974 & 7.02933541 \\
\hline $\mathrm{H}$ & -5.88620534 & 1.13563081 & 7.43014404 \\
\hline $\mathrm{C}$ & -6.42220474 & -1.26217880 & 6.25601424 \\
\hline
\end{tabular}




$\begin{array}{llll}\mathrm{H} & -6.88395925 & -1.40810934 & 7.23964251 \\ \mathrm{H} & -7.11047325 & -0.66391815 & 5.64665024 \\ \mathrm{H} & -6.31094882 & -2.24199488 & 5.78207807 \\ \mathrm{C} & -3.67178723 & 2.68419678 & 7.86454237 \\ \mathrm{H} & -3.35217022 & 3.46272808 & 7.16108869 \\ \mathrm{H} & -4.64131588 & 2.97648694 & 8.27873512 \\ \mathrm{H} & -2.94436212 & 2.65221049 & 8.68403679\end{array}$

C10:

Ce $\quad 1.57682890 \quad-0.11304530 \quad 0.09136038$

$\begin{array}{llll}\text { C } & 3.94576693 & -0.09586422 & 0.71967095\end{array}$

$\begin{array}{llll}\text { C } & 3.19953998 & 0.37463100 & 1.89355558\end{array}$

$\begin{array}{llll}\text { C } & 4.02914551 & 0.76540783 & -0.46587978\end{array}$

$\begin{array}{llll}\text { C } & 3.75844934 & -1.46752882 & 0.21425825\end{array}$

$\begin{array}{llll}\text { C } & 2.66154068 & 1.70563195 & 1.79657810\end{array}$

$\begin{array}{llll}\text { C } & 2.30902128 & -0.59404655 & 2.50679703\end{array}$

C $\quad 3.47268404 \quad 2.10272469 \quad-0.53326382$

C $\quad 3.94905281 \quad-0.05908608 \quad-1.63754108$

C $\quad 3.77646707 \quad-1.41537815 \quad-1.22891124$

$\begin{array}{llll}\text { C } & 2.84076118 & -2.41329379 & 0.83218294\end{array}$

$\begin{array}{llll}\text { C } & 2.83940117 & 2.57343754 & 0.64760349\end{array}$

$\begin{array}{llll}\text { C } & 1.39208313 & 2.10045918 & 2.40929635\end{array}$

C $\quad 2.13486647 \quad-1.94401106 \quad 1.98633959$

$\begin{array}{llll}\text { C } & 1.00514531 & -0.18773526 & 3.02490017\end{array}$

C $\quad 3.00853276 \quad 2.59242758 \quad-1.78331364$

C $\quad 3.43371077 \quad 0.41022868 \quad-2.90123151$

C $\quad 3.08904514 \quad-2.35350266 \quad-2.08339220$

$\begin{array}{llll}\text { C } & 2.16482756 & -3.34295888 & 0.00250866\end{array}$ 


\begin{tabular}{|c|c|c|c|}
\hline $\mathrm{C}$ & 1.71283047 & 3.47577654 & 0.57558660 \\
\hline $\mathrm{C}$ & 0.56119540 & 1.14632089 & 2.99492910 \\
\hline $\mathrm{C}$ & 0.84750366 & 3.22145420 & 1.67064079 \\
\hline $\mathrm{C}$ & 0.74028462 & -2.31696025 & 2.18106538 \\
\hline $\mathrm{C}$ & 0.07328202 & -1.27463781 & 2.85142476 \\
\hline $\mathrm{C}$ & 1.87562288 & 3.48281431 & -1.86544114 \\
\hline $\mathrm{C}$ & 2.97408685 & 1.75005624 & -2.95613011 \\
\hline $\mathrm{C}$ & 2.84089509 & -0.52516211 & -3.76817937 \\
\hline $\mathrm{C}$ & 2.67011046 & -1.91568063 & -3.36104050 \\
\hline $\mathrm{C}$ & 2.31541918 & -3.35452632 & -1.44653834 \\
\hline $\mathrm{C}$ & 0.81823433 & -3.80452741 & 0.28758944 \\
\hline $\mathrm{C}$ & 1.20443386 & 3.92737356 & -0.69526577 \\
\hline $\mathrm{C}$ & -0.90353436 & 1.45454825 & 3.24440985 \\
\hline $\mathrm{C}$ & -0.57463314 & 3.40047343 & 1.54083734 \\
\hline $\mathrm{C}$ & 0.04091042 & -3.22870786 & 1.31747855 \\
\hline $\mathrm{C}$ & -1.34191324 & -1.05535857 & 2.68842305 \\
\hline $\mathrm{C}$ & 1.14508091 & 3.17554230 & -3.06822717 \\
\hline $\mathrm{C}$ & 1.82671616 & 2.10585641 & -3.74241718 \\
\hline $\mathrm{C}$ & 1.72226564 & -0.15747897 & -4.59916671 \\
\hline $\mathrm{C}$ & 1.46714220 & -2.41982036 & -3.96334656 \\
\hline $\mathrm{C}$ & 1.11761014 & -3.86199408 & -2.04499185 \\
\hline $\mathrm{C}$ & 0.21395152 & -4.18504653 & -0.96368656 \\
\hline $\mathrm{C}$ & -0.17589054 & 4.19743040 & -0.79831317 \\
\hline $\mathrm{C}$ & -1.80326311 & 0.25420238 & 2.87985208 \\
\hline $\mathrm{C}$ & -1.42381248 & 2.51134386 & 2.23927765 \\
\hline $\mathrm{C}$ & -1.12965543 & 1.95984327 & 4.72707315 \\
\hline $\mathrm{C}$ & -1.06743175 & 3.94058593 & 0.32230209 \\
\hline $\mathrm{C}$ & -1.39620542 & -3.06996383 & 1.14729506 \\
\hline
\end{tabular}




\begin{tabular}{|c|c|c|c|}
\hline $\mathrm{C}$ & -2.09074949 & -1.97690459 & 1.83235329 \\
\hline $\mathrm{C}$ & -0.26756082 & 3.30924160 & -3.13234621 \\
\hline $\mathrm{C}$ & 1.12088735 & 1.13077253 & -4.50304442 \\
\hline $\mathrm{C}$ & 0.91150701 & -1.34041981 & -4.75870070 \\
\hline $\mathrm{C}$ & 0.61920223 & -3.32413317 & -3.27168099 \\
\hline $\mathrm{C}$ & -1.15084699 & -4.07518446 & -1.11877233 \\
\hline $\mathrm{C}$ & -0.89727593 & 3.94380103 & -2.02318013 \\
\hline $\mathrm{C}$ & -2.91399662 & 0.73444601 & 2.14762608 \\
\hline $\mathrm{C}$ & -2.65376671 & 2.10492152 & 1.70420316 \\
\hline $\mathrm{H}$ & -2.19599683 & 2.19357463 & 4.81382754 \\
\hline $\mathrm{C}$ & -0.71437636 & 0.95703558 & 5.78491970 \\
\hline $\mathrm{H}$ & -0.56262175 & 2.89045211 & 4.83780802 \\
\hline $\mathrm{C}$ & -2.34325112 & 3.54864287 & -0.20311258 \\
\hline $\mathrm{C}$ & -1.97418804 & -3.59767064 & -0.04661813 \\
\hline $\mathrm{C}$ & -3.30700492 & -1.49711283 & 1.27324159 \\
\hline $\mathrm{C}$ & -1.03028206 & 2.35381746 & -3.95180629 \\
\hline $\mathrm{C}$ & -0.33140014 & 1.26368647 & -4.64353222 \\
\hline $\mathrm{C}$ & -0.44409231 & -1.22188300 & -4.94362935 \\
\hline $\mathrm{C}$ & -0.84003681 & -3.20109046 & -3.45138806 \\
\hline $\mathrm{C}$ & -1.70271332 & -3.60677930 & -2.39524429 \\
\hline $\mathrm{C}$ & -2.24760841 & 3.60567237 & -1.65284111 \\
\hline $\mathrm{C}$ & -3.67886113 & -0.11975163 & 1.38022141 \\
\hline $\mathrm{C}$ & -3.12903163 & 2.55847316 & 0.42990042 \\
\hline $\mathrm{C}$ & -1.60325060 & -0.03512312 & 6.20737121 \\
\hline $\mathrm{C}$ & 0.56860503 & 1.01264949 & 6.34987044 \\
\hline $\mathrm{C}$ & -3.11588921 & -2.96234111 & -0.66455111 \\
\hline $\mathrm{C}$ & -3.76715744 & -1.94627854 & -0.02630850 \\
\hline $\mathrm{C}$ & -2.40238741 & 2.17346198 & -3.63042523 \\
\hline
\end{tabular}




\begin{tabular}{|c|c|c|c|}
\hline $\mathrm{C}$ & -1.06505163 & 0.08094054 & -4.94895698 \\
\hline $\mathrm{C}$ & -1.34564418 & -2.17711812 & -4.30334328 \\
\hline $\mathrm{C}$ & -2.92575536 & -2.92683194 & -2.11518611 \\
\hline $\mathrm{C}$ & -2.97847518 & 2.74539280 & -2.43347930 \\
\hline $\mathrm{C}$ & -4.21144273 & 0.33195048 & 0.09188929 \\
\hline $\mathrm{C}$ & -3.92260604 & 1.63583917 & -0.39933492 \\
\hline $\mathrm{C}$ & -1.22680826 & -0.97286466 & 7.17991576 \\
\hline $\mathrm{H}$ & -2.60009941 & -0.07960882 & 5.78031406 \\
\hline $\mathrm{C}$ & 0.96656927 & 0.09058056 & 7.32105590 \\
\hline $\mathrm{H}$ & 1.25916198 & 1.78880458 & 6.03499627 \\
\hline $\mathrm{C}$ & -4.27764990 & -0.80109489 & -0.77200092 \\
\hline $\mathrm{C}$ & -3.05934272 & 0.90607364 & -3.82687659 \\
\hline $\mathrm{C}$ & -2.40906745 & -0.11133982 & -4.46959596 \\
\hline $\mathrm{C}$ & -2.56853563 & -1.49450497 & -4.01807205 \\
\hline $\mathrm{C}$ & -3.33998398 & -1.79249417 & -2.86545998 \\
\hline $\mathrm{C}$ & -3.86190096 & 1.76479387 & -1.81520356 \\
\hline $\mathrm{C}$ & 0.05762833 & -0.89872217 & 7.72502632 \\
\hline $\mathrm{C}$ & -2.20827889 & -2.04237406 & 7.62839369 \\
\hline $\mathrm{C}$ & 2.35356846 & 0.15164125 & 7.93795275 \\
\hline $\mathrm{C}$ & -4.04153998 & -0.69087827 & -2.17356358 \\
\hline $\mathrm{C}$ & -3.92403143 & 0.62474465 & -2.68122867 \\
\hline $\mathrm{H}$ & 0.35650861 & -1.61905594 & 8.48060518 \\
\hline $\mathrm{H}$ & -1.75546672 & -2.69844472 & 8.37760622 \\
\hline $\mathrm{H}$ & -3.10461418 & -1.58853049 & 8.06784089 \\
\hline $\mathrm{H}$ & -2.52519455 & -2.65951035 & 6.77930514 \\
\hline $\mathrm{H}$ & 2.90644776 & -0.77537421 & 7.74410533 \\
\hline $\mathrm{H}$ & 2.92927921 & 0.98530996 & 7.52488863 \\
\hline $\mathrm{H}$ & 2.29056240 & 0.28468712 & 9.02447561 \\
\hline
\end{tabular}




\section{C14:}

Ce $\quad \begin{array}{llll}1.85804554 & -1.26064085 & -0.23382552\end{array}$

$\begin{array}{lllll}\text { C } & & -0.71652797 & -3.86818067 & -0.22672974\end{array}$

$\begin{array}{llll}\text { C } & 2.75489921 & -2.68646104 & -2.17046246\end{array}$

C $\quad \begin{array}{llll}1.47264585 & -2.58353876 & -2.85627793\end{array}$

$\begin{array}{llll}\text { C } & 0.28107656 & -3.19889222 & -2.37392401\end{array}$

C $\quad \begin{array}{llll}0.38007566 & -3.89489640 & -1.14500327\end{array}$

C $\quad \begin{array}{llll} & 1.63637641 & -3.93145396 & -0.39382787\end{array}$

C $\quad \begin{array}{llll} & 2.87649241 & -3.39670127 & -0.90301388\end{array}$

$\begin{array}{llll}\text { C } & 1.39742928 & -1.31587967 & -3.52322629\end{array}$

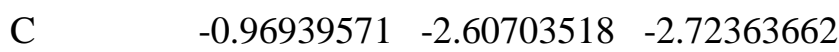

$\begin{array}{llll}\text { C } & -1.95733655 & -3.21747400 & -0.54041274\end{array}$

$\begin{array}{llll}\text { C } & 0.16101114 & -0.64868212 & -3.79994625\end{array}$

$\begin{array}{llll}\text { C } & -2.07582469 & -2.63254432 & -1.83042629\end{array}$

$\begin{array}{llll}\text { C } & -2.84620494 & -1.38761151 & -2.02404789\end{array}$

$\begin{array}{llll}\text { C } & -2.20797627 & -0.66943796 & -3.10969700\end{array}$

$\begin{array}{lllll}\text { C } & -3.44029753 & -0.70473479 & -0.97683513\end{array}$

$\begin{array}{lllll}\text { C } & & -1.01520235 & -1.36299498 & -3.49161849\end{array}$

$\begin{array}{lllll}\text { C } & & -2.25191995 & 0.70710380 & -3.16355546\end{array}$

$\begin{array}{lllll}\text { C } & & -3.49927975 & 0.75211805 & -1.00515893\end{array}$

$\begin{array}{llll}\text { C } & -2.92772319 & 1.44053697 & -2.11328867\end{array}$

$\begin{array}{lllll}\text { C } & 0.14719605 & 0.81687934 & -3.83216795\end{array}$

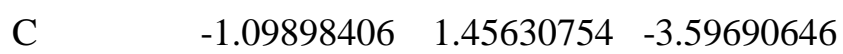

$\begin{array}{llll}\text { C } & -2.27193810 & 2.71183332 & -1.96836472\end{array}$

$\begin{array}{llll}\text { C } & -2.14117988 & 3.32737940 & -0.70524544\end{array}$

$\begin{array}{llll}\text { C } & -1.16980039 & 2.73527807 & -2.92445970\end{array}$

$\begin{array}{llll}\text { C } & 4.44332114 & -0.70231774 & 0.99884494\end{array}$ 


\begin{tabular}{|c|c|c|c|}
\hline $\mathrm{C}$ & 1.38805341 & -2.53447875 & 3.03790283 \\
\hline $\mathrm{C}$ & 3.44822024 & -1.42395051 & -2.43152426 \\
\hline $\mathrm{C}$ & -0.05346879 & -2.48111500 & 3.11034573 \\
\hline $\mathrm{C}$ & 1.88576661 & -1.29802553 & 3.58600242 \\
\hline $\mathrm{C}$ & 4.30129478 & -0.80377895 & -1.46263328 \\
\hline $\mathrm{C}$ & -0.84287308 & -3.11668404 & 2.12733603 \\
\hline $\mathrm{C}$ & 3.06964775 & -0.71011874 & 3.08388221 \\
\hline $\mathrm{C}$ & 4.44518801 & -1.50396344 & -0.19967123 \\
\hline $\mathrm{C}$ & -0.18057253 & -3.84455435 & 1.09976851 \\
\hline $\mathrm{C}$ & 3.75284246 & -1.41420029 & 2.02546166 \\
\hline $\mathrm{C}$ & 3.75419160 & -2.77312981 & 0.09334944 \\
\hline $\mathrm{C}$ & 1.25778980 & -3.89014511 & 1.01336735 \\
\hline $\mathrm{C}$ & 3.30949633 & -2.67096604 & 1.49281994 \\
\hline $\mathrm{C}$ & 2.05273212 & -3.20411229 & 1.97097114 \\
\hline $\mathrm{C}$ & 2.58770023 & -0.59842419 & -3.24844359 \\
\hline $\mathrm{C}$ & -0.43359741 & -1.21000433 & 3.68421167 \\
\hline $\mathrm{C}$ & 0.75858184 & -0.48358367 & 3.97219362 \\
\hline $\mathrm{C}$ & 4.35630049 & 0.61168355 & -1.46866308 \\
\hline $\mathrm{C}$ & -2.10310965 & -2.51492215 & 1.80498215 \\
\hline $\mathrm{C}$ & 3.18814776 & 0.69427298 & 3.13977407 \\
\hline $\mathrm{C}$ & 4.48880128 & 0.73785555 & 1.00839941 \\
\hline $\mathrm{C}$ & 2.60641461 & 0.83347523 & -3.23336050 \\
\hline $\mathrm{C}$ & -1.62293829 & -0.53663971 & 3.27900399 \\
\hline $\mathrm{C}$ & 0.81158282 & 0.94163915 & 3.88340990 \\
\hline $\mathrm{C}$ & 4.49868308 & 1.39268442 & -0.24517373 \\
\hline $\mathrm{C}$ & -2.66431230 & -2.60184433 & 0.52323836 \\
\hline $\mathrm{C}$ & 3.89740695 & 1.41950285 & 2.10202609 \\
\hline $\mathrm{C}$ & 3.87378266 & 2.67014149 & -0.42459840 \\
\hline
\end{tabular}




\begin{tabular}{|c|c|c|c|}
\hline $\mathrm{C}$ & -3.70024721 & -1.47577678 & 0.32374063 \\
\hline $\mathrm{C}$ & 3.26799613 & 2.70219490 & 1.92450351 \\
\hline $\mathrm{C}$ & 3.35229832 & 2.69488799 & -1.77343374 \\
\hline $\mathrm{C}$ & -3.39613792 & -0.60398395 & 1.54169913 \\
\hline $\mathrm{C}$ & 2.17305164 & 2.76407045 & 2.86945481 \\
\hline $\mathrm{C}$ & 3.15632385 & 3.29592811 & 0.63924255 \\
\hline $\mathrm{C}$ & 3.58545300 & 1.41518043 & -2.39599468 \\
\hline $\mathrm{C}$ & -2.51283580 & -1.25828287 & 2.43349142 \\
\hline $\mathrm{C}$ & 2.07979257 & 1.50993823 & 3.57721508 \\
\hline $\mathrm{C}$ & 2.21595851 & 3.40581225 & -2.08731925 \\
\hline $\mathrm{C}$ & -3.44310245 & 0.76391624 & 1.51255109 \\
\hline $\mathrm{C}$ & 1.03041176 & 3.47634877 & 2.58868781 \\
\hline $\mathrm{C}$ & 1.93322509 & 4.05805728 & 0.31827480 \\
\hline $\mathrm{C}$ & 1.50156809 & 4.13277555 & -1.03464279 \\
\hline $\mathrm{C}$ & -3.53091052 & 1.47601648 & 0.22467888 \\
\hline $\mathrm{C}$ & 0.90680298 & 4.16062270 & 1.30109336 \\
\hline $\mathrm{C}$ & 1.37905492 & 1.55918397 & -3.54350062 \\
\hline $\mathrm{C}$ & -1.63613099 & 0.92293057 & 3.24143276 \\
\hline $\mathrm{C}$ & -0.40961568 & 1.67018826 & 3.54294884 \\
\hline $\mathrm{C}$ & 1.26135771 & 2.88282740 & -3.02612994 \\
\hline $\mathrm{C}$ & -2.60891145 & 1.53214339 & 2.39974220 \\
\hline $\mathrm{C}$ & -0.25842996 & 2.97204671 & 2.98039590 \\
\hline $\mathrm{C}$ & 0.11626176 & 4.15064769 & -1.38401657 \\
\hline $\mathrm{C}$ & -2.86573117 & 2.72160906 & 0.36849811 \\
\hline $\mathrm{C}$ & -0.47739075 & 4.17911128 & 0.94962397 \\
\hline $\mathrm{C}$ & -0.90539593 & 4.07930853 & -0.39903334 \\
\hline $\mathrm{C}$ & -0.02188992 & 3.42284793 & -2.64529854 \\
\hline $\mathrm{C}$ & -2.34240404 & 2.78259383 & 1.73327555 \\
\hline
\end{tabular}




$\begin{array}{llll}\mathrm{C} & -1.20122290 & 3.47979880 & 2.01387692 \\ \mathrm{C} & -5.16228737 & -2.08501416 & 0.34709205 \\ \mathrm{H} & -5.21631894 & -2.80495130 & -0.47626333 \\ \mathrm{H} & -5.26027890 & -2.63228586 & 1.29036239 \\ \mathrm{C} & -6.26077768 & -1.04941956 & 0.21331023 \\ \mathrm{C} & -6.77862467 & -0.41449472 & 1.34477394 \\ \mathrm{C} & -7.79169535 & 0.54918708 & 1.22989538 \\ \mathrm{C} & -8.27742201 & 0.86641524 & -0.04090656 \\ \mathrm{C} & -7.77568605 & 0.24056310 & -1.19203083 \\ \mathrm{C} & -6.76769679 & -0.71598967 & -1.05161208 \\ \mathrm{H} & -6.39483511 & -0.67125603 & 2.32706001 \\ \mathrm{H} & -9.06227321 & 1.61021723 & -0.13962059 \\ \mathrm{H} & -6.37357377 & -1.21085652 & -1.93331213 \\ \mathrm{C} & -8.34508368 & 1.22545235 & 2.47262292 \\ \mathrm{H} & -9.11049803 & 1.96131444 & 2.20879822 \\ \mathrm{H} & -8.79700454 & 0.48895205 & 3.14789732 \\ \mathrm{H} & -7.54832023 & 1.74134980 & 3.02132935 \\ \mathrm{H} & -8.32678536 & 0.60189157 & -2.56090502 \\ \mathrm{H} & -7.83551864 & 0.01961626 & -3.34620726 \\ \mathrm{H} & -9.40430195 & 0.40495625 & -2.61186018 \\ \mathrm{H} & -8.16823338 & 1.66567806 & -2.77466599\end{array}$

C18:

$\begin{array}{llll}\mathrm{Ce} & -2.00828130 & -0.94473514 & -0.61432804 \\ \mathrm{C} & -1.34881399 & -3.91355000 & 0.53124432 \\ \mathrm{C} & -4.20402503 & -1.15261891 & 1.39903718 \\ \mathrm{C} & -3.35800938 & -1.58293840 & 2.49212503 \\ \mathrm{C} & -2.50452845 & -2.70372058 & 2.35228807\end{array}$




\begin{tabular}{|c|c|c|c|}
\hline $\mathrm{C}$ & -2.54766323 & -3.37890575 & 1.08065823 \\
\hline $\mathrm{C}$ & -3.44290226 & -3.00683783 & -0.00137805 \\
\hline $\mathrm{C}$ & -4.29527445 & -1.84924445 & 0.14836953 \\
\hline $\mathrm{C}$ & -2.94963185 & -0.42958251 & 3.24249913 \\
\hline $\mathrm{C}$ & -1.30428751 & -2.71341467 & 3.09190310 \\
\hline $\mathrm{C}$ & -0.09702153 & -3.86636214 & 1.23901383 \\
\hline $\mathrm{C}$ & -1.67622097 & -0.36780913 & 3.87435486 \\
\hline $\mathrm{C}$ & -0.09558303 & -3.30983651 & 2.54374736 \\
\hline $\mathrm{C}$ & 1.03646611 & -2.57272447 & 3.02745800 \\
\hline $\mathrm{C}$ & 0.52549489 & -1.52983813 & 3.89248600 \\
\hline $\mathrm{C}$ & 2.17636185 & -2.34112849 & 2.20493417 \\
\hline $\mathrm{C}$ & -0.91619900 & -1.56982793 & 3.88619229 \\
\hline $\mathrm{C}$ & 1.17560912 & -0.32142475 & 3.99674873 \\
\hline $\mathrm{C}$ & 2.86209142 & -1.04939107 & 2.30579319 \\
\hline $\mathrm{C}$ & 2.37945731 & -0.07823324 & 3.22206119 \\
\hline $\mathrm{C}$ & -0.98952745 & 0.93052149 & 3.94481982 \\
\hline $\mathrm{C}$ & 0.42001986 & 0.91021116 & 4.09660209 \\
\hline $\mathrm{C}$ & 2.42906940 & 1.32927861 & 2.92681915 \\
\hline $\mathrm{C}$ & 2.96015281 & 1.83065730 & 1.71947428 \\
\hline $\mathrm{C}$ & 1.25095577 & 1.94468405 & 3.53059729 \\
\hline $\mathrm{C}$ & -3.91826864 & 1.00741906 & -2.03248061 \\
\hline $\mathrm{C}$ & -1.64909932 & -2.17379281 & -3.14452532 \\
\hline $\mathrm{C}$ & -4.32749103 & 0.28794798 & 1.52269355 \\
\hline $\mathrm{C}$ & -0.36533077 & -2.76510277 & -2.78759486 \\
\hline $\mathrm{C}$ & -1.34806750 & -0.90343122 & -3.76255119 \\
\hline $\mathrm{C}$ & -4.48343951 & 1.09800392 & 0.37154030 \\
\hline $\mathrm{C}$ & -0.24024333 & -3.58684987 & -1.64933747 \\
\hline $\mathrm{C}$ & -2.22466615 & 0.20106891 & -3.63673025 \\
\hline
\end{tabular}




\begin{tabular}{|c|c|c|c|}
\hline $\mathrm{C}$ & -4.53567591 & 0.40811970 & -0.89320314 \\
\hline $\mathrm{C}$ & -1.43296892 & -3.82897068 & -0.89677048 \\
\hline $\mathrm{C}$ & -3.42961924 & -0.03707153 & -2.87935433 \\
\hline $\mathrm{C}$ & -4.50082616 & -1.03695580 & -1.03885304 \\
\hline $\mathrm{C}$ & -2.73792710 & -3.29859300 & -1.26496807 \\
\hline $\mathrm{C}$ & -3.79898223 & -1.32642062 & -2.31149704 \\
\hline $\mathrm{C}$ & -2.87255307 & -2.44694471 & -2.43143305 \\
\hline $\mathrm{C}$ & -3.55169224 & 0.72569905 & 2.64356327 \\
\hline $\mathrm{C}$ & 0.68164506 & -1.85722326 & -3.15426542 \\
\hline $\mathrm{C}$ & 0.08312843 & -0.71074016 & -3.74705825 \\
\hline $\mathrm{C}$ & -3.95634341 & 2.40566642 & 0.41640615 \\
\hline $\mathrm{C}$ & 1.02020500 & -3.59507847 & -0.97932075 \\
\hline $\mathrm{C}$ & -1.66012524 & 1.49512529 & -3.64778403 \\
\hline $\mathrm{C}$ & -3.31808663 & 2.31529645 & -1.98408608 \\
\hline $\mathrm{C}$ & -2.89864501 & 1.99237180 & 2.64473652 \\
\hline $\mathrm{C}$ & 1.88883847 & -1.74255451 & -2.39621985 \\
\hline $\mathrm{C}$ & 0.66385402 & 0.57620611 & -3.61502598 \\
\hline $\mathrm{C}$ & -3.38995986 & 3.03007401 & -0.76338581 \\
\hline $\mathrm{C}$ & 1.08953846 & -3.75795518 & 0.47340675 \\
\hline C & -2.21008532 & 2.56027334 & -2.83219176 \\
\hline $\mathrm{C}$ & -2.31815621 & 3.90024448 & -0.35117155 \\
\hline $\mathrm{C}$ & 2.21756280 & -3.02802690 & 0.95840707 \\
\hline $\mathrm{C}$ & -1.13605558 & 3.42570847 & -2.41726025 \\
\hline $\mathrm{C}$ & -2.25126769 & 3.82716030 & 1.09602124 \\
\hline $\mathrm{C}$ & 2.87532309 & -2.44304321 & -0.19505393 \\
\hline $\mathrm{C}$ & 0.07349947 & 2.90066929 & -2.98912695 \\
\hline $\mathrm{C}$ & -1.13588890 & 4.03248870 & -1.12241612 \\
\hline $\mathrm{C}$ & -3.21400743 & 2.86726681 & 1.57150353 \\
\hline
\end{tabular}




\begin{tabular}{|c|c|c|c|}
\hline $\mathrm{C}$ & 2.08298884 & -2.74270020 & -1.38399215 \\
\hline $\mathrm{C}$ & -0.22402977 & 1.68098834 & -3.68825275 \\
\hline $\mathrm{C}$ & -1.05953176 & 3.99002139 & 1.76198794 \\
\hline $\mathrm{C}$ & 3.52889191 & -1.25104113 & -0.09386825 \\
\hline $\mathrm{C}$ & 1.29701561 & 3.03940874 & -2.34508850 \\
\hline $\mathrm{C}$ & 0.15349980 & 4.19311610 & -0.42213017 \\
\hline $\mathrm{C}$ & 0.16729988 & 4.20459629 & 1.00129123 \\
\hline $\mathrm{C}$ & 3.53238489 & -0.53978754 & 1.14966945 \\
\hline $\mathrm{C}$ & 1.34306138 & 3.72712054 & -1.05063547 \\
\hline $\mathrm{C}$ & -1.60560370 & 2.11730557 & 3.32743790 \\
\hline $\mathrm{C}$ & 2.51835513 & -0.45972781 & -2.28330415 \\
\hline $\mathrm{C}$ & 1.94025156 & 0.69942721 & -2.88258178 \\
\hline $\mathrm{C}$ & -0.75874026 & 3.18010036 & 2.91720436 \\
\hline $\mathrm{C}$ & 3.69356487 & -0.30199132 & -1.28265843 \\
\hline $\mathrm{C}$ & 2.27703327 & 2.01089543 & -2.37488958 \\
\hline $\mathrm{C}$ & 1.24871005 & 3.63529618 & 1.74871039 \\
\hline $\mathrm{C}$ & 3.57416793 & 0.86596162 & 0.85919282 \\
\hline $\mathrm{C}$ & 2.41867480 & 3.16269393 & -0.30381196 \\
\hline $\mathrm{C}$ & 2.35640406 & 3.02313622 & 1.10653599 \\
\hline $\mathrm{C}$ & 0.68114044 & 3.04720229 & 2.95483911 \\
\hline $\mathrm{C}$ & 3.61040178 & 1.03994506 & -0.55946366 \\
\hline $\mathrm{C}$ & 3.02932625 & 2.12819813 & -1.13487966 \\
\hline $\mathrm{C}$ & 5.05479013 & -0.50834562 & -2.05594781 \\
\hline $\mathrm{H}$ & 5.01431667 & -1.50125685 & -2.51601854 \\
\hline $\mathrm{H}$ & 5.08107409 & 0.23958791 & -2.85504679 \\
\hline $\mathrm{C}$ & 6.27470462 & -0.38208154 & -1.16524150 \\
\hline $\mathrm{C}$ & 6.88673553 & 0.85876894 & -0.97376053 \\
\hline $\mathrm{C}$ & 8.00583285 & 0.98836729 & -0.13735225 \\
\hline
\end{tabular}




$\begin{array}{llll}\text { C } & 8.50032941 & -0.14899679 & 0.50568704 \\ \mathrm{C} & 7.90326957 & -1.40633672 & 0.32818339 \\ \mathrm{C} & 6.79031287 & -1.50957587 & -0.50971795 \\ \mathrm{H} & 6.49362737 & 1.73434234 & -1.48105533 \\ \mathrm{H} & 9.36715011 & -0.05892763 & 1.15344827 \\ \mathrm{H} & 6.32076215 & -2.47661179 & -0.65883436 \\ \mathrm{C} & 8.66515024 & 2.34416475 & 0.05101052 \\ \mathrm{H} & 9.48602136 & 2.28230019 & 0.77160234 \\ \mathrm{H} & 9.07101898 & 2.71402486 & -0.89841094 \\ \mathrm{H} & 7.94175589 & 3.08187937 & 0.41765988 \\ \mathrm{C} & 8.46817740 & -2.62742790 & 1.03364130 \\ \mathrm{H} & 9.50509175 & -2.80915470 & 0.72643514 \\ \mathrm{H} & 8.45904390 & -2.48740822 & 2.12114137 \\ \mathrm{H} & 7.88120050 & -3.52055869 & 0.79956831\end{array}$

C19:

$\begin{array}{llll}\mathrm{Ce} & -1.67125889 & 0.06423947 & 0.09736234 \\ \mathrm{C} & -2.53933454 & -2.79168549 & 0.74092549 \\ \mathrm{C} & -2.41032229 & 0.57625936 & 3.01490660 \\ \mathrm{C} & -1.65074100 & -0.54621678 & 3.48667151 \\ \mathrm{C} & -1.81316990 & -1.82342615 & 2.89640270 \\ \mathrm{C} & -2.79713914 & -1.92945718 & 1.85430986 \\ \mathrm{C} & -3.64487296 & -0.83510146 & 1.42215241 \\ \mathrm{C} & -3.41917861 & 0.47478367 & 1.99739714 \\ \mathrm{C} & -0.34390791 & -0.08266893 & 3.90684870 \\ \mathrm{C} & -0.69172054 & -2.67941412 & 2.86595646 \\ \mathrm{C} & -1.35880749 & -3.61054274 & 0.67107015 \\ \mathrm{C} & 0.80692301 & -0.87523076 & 3.74893394\end{array}$




\begin{tabular}{|c|c|c|c|}
\hline $\mathrm{C}$ & -0.47021976 & -3.57865114 & 1.76985185 \\
\hline $\mathrm{C}$ & 0.96728235 & -3.70733873 & 1.58051475 \\
\hline $\mathrm{C}$ & 1.59069579 & -2.91684198 & 2.56632662 \\
\hline $\mathrm{C}$ & 1.52036697 & -3.84532511 & 0.25519289 \\
\hline $\mathrm{C}$ & 0.61312594 & -2.22681863 & 3.32679660 \\
\hline $\mathrm{C}$ & 2.81945094 & -3.19394630 & -0.01971435 \\
\hline $\mathrm{C}$ & 3.45705370 & -2.46494172 & 1.01459581 \\
\hline $\mathrm{C}$ & 2.09809282 & -0.19821756 & 3.44163789 \\
\hline $\mathrm{C}$ & 3.09377944 & -0.96580445 & 2.82157526 \\
\hline $\mathrm{C}$ & 4.18360020 & -1.29001025 & 0.75575058 \\
\hline $\mathrm{C}$ & 4.34445995 & -0.76122522 & -0.56190557 \\
\hline $\mathrm{C}$ & 4.01071349 & -0.38711577 & 1.90038144 \\
\hline $\mathrm{C}$ & -2.37833215 & 3.27901308 & -0.03615348 \\
\hline $\mathrm{C}$ & -3.23735535 & -0.06459738 & -2.19252320 \\
\hline $\mathrm{C}$ & -1.57598414 & 1.75590155 & 3.19027928 \\
\hline $\mathrm{C}$ & -2.57085351 & -1.30249149 & -2.57743255 \\
\hline $\mathrm{C}$ & -2.51816704 & 1.00013720 & -2.87364332 \\
\hline $\mathrm{C}$ & -1.68262159 & 2.85406959 & 2.30168788 \\
\hline $\mathrm{C}$ & -2.51468874 & -2.40127464 & -1.68728180 \\
\hline $\mathrm{C}$ & -2.39215642 & 2.28954872 & -2.29652819 \\
\hline $\mathrm{C}$ & -2.66273702 & 2.73921038 & 1.25593923 \\
\hline $\mathrm{C}$ & -3.16498342 & -2.23087265 & -0.41567902 \\
\hline $\mathrm{C}$ & -3.02176765 & 2.46450693 & -1.01366927 \\
\hline $\mathrm{C}$ & -3.54177106 & 1.60381195 & 1.10325178 \\
\hline $\mathrm{C}$ & -3.89814024 & -1.02292440 & -0.02765662 \\
\hline $\mathrm{C}$ & -3.78706923 & 1.42715991 & -0.34004423 \\
\hline $\mathrm{C}$ & -3.93276513 & 0.10951420 & -0.94127951 \\
\hline $\mathrm{C}$ & -0.31016130 & 1.34589057 & 3.70929463 \\
\hline
\end{tabular}




\begin{tabular}{|c|c|c|c|}
\hline $\mathrm{C}$ & -1.47588318 & -0.99177400 & -3.44766781 \\
\hline $\mathrm{C}$ & -1.44012766 & 0.42638484 & -3.62090566 \\
\hline $\mathrm{C}$ & -0.52431518 & 3.62477921 & 2.07088293 \\
\hline $\mathrm{C}$ & -1.37993830 & -3.25094808 & -1.77320642 \\
\hline $\mathrm{C}$ & -1.24736792 & 3.04530904 & -2.61307757 \\
\hline $\mathrm{C}$ & -1.17012994 & 4.00881482 & -0.31258427 \\
\hline $\mathrm{C}$ & 0.88931871 & 2.03284182 & 3.37463483 \\
\hline $\mathrm{C}$ & -0.27934795 & -1.77023491 & -3.46193364 \\
\hline $\mathrm{C}$ & -0.21619735 & 1.12954034 & -3.84544129 \\
\hline $\mathrm{C}$ & -0.26641293 & 4.21914160 & 0.75703617 \\
\hline $\mathrm{C}$ & -0.82346530 & -3.88556992 & -0.61325340 \\
\hline $\mathrm{C}$ & -0.63236594 & 3.92100815 & -1.62215770 \\
\hline $\mathrm{C}$ & 1.14677956 & 4.24880978 & 0.53570879 \\
\hline $\mathrm{C}$ & 0.61246886 & -4.02141246 & -0.80538546 \\
\hline $\mathrm{C}$ & 0.78209776 & 3.94670612 & -1.84252358 \\
\hline $\mathrm{C}$ & 1.76816956 & 3.68430240 & 1.72060446 \\
\hline $\mathrm{C}$ & 0.90320588 & -3.49471536 & -2.12542107 \\
\hline $\mathrm{C}$ & 1.04562329 & 3.09311430 & -2.98711140 \\
\hline $\mathrm{C}$ & 1.70050252 & 4.01163399 & -0.75547091 \\
\hline $\mathrm{C}$ & 0.73723500 & 3.24243987 & 2.63862059 \\
\hline $\mathrm{C}$ & -0.30101290 & -2.96954232 & -2.70684018 \\
\hline $\mathrm{C}$ & -0.18882747 & 2.48399366 & -3.42060908 \\
\hline $\mathrm{C}$ & 2.94504009 & 2.99183063 & 1.63825662 \\
\hline $\mathrm{C}$ & 2.11372716 & -2.90078022 & -2.40456849 \\
\hline $\mathrm{C}$ & 2.22259124 & 2.39414506 & -3.09040087 \\
\hline $\mathrm{C}$ & 2.96530961 & 3.26177308 & -0.85513782 \\
\hline $\mathrm{C}$ & 3.58574081 & 2.79295348 & 0.33939487 \\
\hline $\mathrm{C}$ & 3.09938623 & -2.75996448 & -1.34532245 \\
\hline
\end{tabular}




\begin{tabular}{|c|c|c|c|}
\hline $\mathrm{C}$ & 3.22308376 & 2.49697967 & -2.02690775 \\
\hline $\mathrm{C}$ & 2.12327393 & 1.25831658 & 3.25230088 \\
\hline $\mathrm{C}$ & 0.99698714 & -1.09715877 & -3.72760544 \\
\hline $\mathrm{C}$ & 1.02768601 & 0.36218976 & -3.91723383 \\
\hline $\mathrm{C}$ & 3.16310474 & 1.81446011 & 2.45772900 \\
\hline $\mathrm{C}$ & 2.17287981 & -1.73843769 & -3.25578946 \\
\hline $\mathrm{C}$ & 2.23601226 & 1.05468677 & -3.62632629 \\
\hline $\mathrm{C}$ & 4.27746980 & 1.54611852 & 0.39013993 \\
\hline $\mathrm{C}$ & 3.86230699 & -1.57294459 & -1.61005933 \\
\hline $\mathrm{C}$ & 3.91783633 & 1.25026001 & -1.97175971 \\
\hline $\mathrm{C}$ & 4.38271738 & 0.70321802 & -0.74456208 \\
\hline $\mathrm{C}$ & 4.05762993 & 0.97543549 & 1.72439579 \\
\hline $\mathrm{C}$ & 3.32369600 & -0.97368438 & -2.82416012 \\
\hline $\mathrm{C}$ & 3.34731033 & 0.38173852 & -3.00016756 \\
\hline $\mathrm{C}$ & 2.99592935 & -2.46223516 & 2.48766114 \\
\hline $\mathrm{C}$ & 3.99537589 & -3.32463444 & 3.36623981 \\
\hline $\mathrm{H}$ & 3.93837604 & -4.35089150 & 2.98921595 \\
\hline $\mathrm{H}$ & 5.00192782 & -2.93957363 & 3.17173890 \\
\hline $\mathrm{C}$ & 3.68498422 & -3.28196785 & 4.84798495 \\
\hline $\mathrm{C}$ & 4.26668756 & -2.30040529 & 5.66364318 \\
\hline $\mathrm{C}$ & 2.81391116 & -4.21400567 & 5.41818436 \\
\hline $\mathrm{C}$ & 3.98627712 & -2.24387035 & 7.03106269 \\
\hline $\mathrm{H}$ & 4.95206220 & -1.57980200 & 5.22891948 \\
\hline $\mathrm{C}$ & 2.51668323 & -4.17818320 & 6.78812795 \\
\hline $\mathrm{H}$ & 2.36320899 & -4.97850134 & 4.79324848 \\
\hline $\mathrm{C}$ & 3.10865717 & -3.19068934 & 7.57978833 \\
\hline $\mathrm{H}$ & 2.88875182 & -3.15853069 & 8.64269698 \\
\hline $\mathrm{C}$ & 4.61151834 & -1.17795957 & 7.91481844 \\
\hline
\end{tabular}




\begin{tabular}{|c|c|c|c|}
\hline $\mathrm{H}$ & 3.84666736 & -0.48283525 & 8.28251625 \\
\hline $\mathrm{H}$ & 5.10207253 & -1.62952822 & 8.78485818 \\
\hline $\mathrm{H}$ & 5.35823705 & -0.59967180 & 7.36228743 \\
\hline $\mathrm{C}$ & 1.55754611 & -5.19214528 & 7.38825490 \\
\hline $\mathrm{H}$ & 1.56399338 & -5.13768916 & 8.48106228 \\
\hline & 0.53305036 & -5.00459974 & 7.04345306 \\
\hline & 1.83043279 & -6.21168136 & 7.09304724 \\
\hline
\end{tabular}

C23:

\begin{tabular}{|c|c|c|c|}
\hline $\mathrm{Ce}$ & -1.76715669 & -1.17569551 & -0.71501486 \\
\hline $\mathrm{C}$ & -1.47849664 & -3.89675388 & 0.53330632 \\
\hline $\mathrm{C}$ & -4.19408103 & -1.01670812 & 1.54448479 \\
\hline $\mathrm{C}$ & -3.32129497 & -1.48121905 & 2.59524147 \\
\hline $\mathrm{C}$ & -2.50842025 & -2.62216626 & 2.39948028 \\
\hline $\mathrm{C}$ & -2.62754147 & -3.29667357 & 1.13460133 \\
\hline $\mathrm{C}$ & -3.54510026 & -2.89765141 & 0.09383578 \\
\hline $\mathrm{C}$ & -4.30340880 & -1.68389053 & 0.29165704 \\
\hline $\mathrm{C}$ & -2.83912252 & -0.33977832 & 3.32765050 \\
\hline $\mathrm{C}$ & -1.26732869 & -2.67230754 & 3.07731037 \\
\hline $\mathrm{C}$ & -0.19736041 & -3.88331015 & 1.19114401 \\
\hline $\mathrm{C}$ & -1.53402982 & -0.31791414 & 3.87340106 \\
\hline $\mathrm{C}$ & -0.11889794 & -3.31874141 & 2.48835013 \\
\hline $\mathrm{C}$ & 1.06456163 & -2.59857044 & 2.91178814 \\
\hline $\mathrm{C}$ & 0.63330701 & -1.54904928 & 3.78935208 \\
\hline $\mathrm{C}$ & 2.16852562 & -2.40096611 & 2.03561001 \\
\hline $\mathrm{C}$ & -0.80305372 & -1.54096404 & 3.85328235 \\
\hline $\mathrm{C}$ & 1.33600969 & -0.35054779 & 3.84990702 \\
\hline $\mathrm{C}$ & 2.92152463 & -1.13397508 & 2.11236190 \\
\hline
\end{tabular}




\begin{tabular}{|c|c|c|c|}
\hline $\mathrm{C}$ & 2.49749131 & -0.14596601 & 3.05519977 \\
\hline $\mathrm{C}$ & -0.80460569 & 0.96749124 & 3.90337243 \\
\hline $\mathrm{C}$ & 0.60386550 & 0.90618771 & 3.97524460 \\
\hline $\mathrm{C}$ & 2.56329604 & 1.28875877 & 2.72387433 \\
\hline $\mathrm{C}$ & 3.03415292 & 1.76150061 & 1.51781529 \\
\hline $\mathrm{C}$ & 1.42910119 & 1.92244675 & 3.37798528 \\
\hline $\mathrm{C}$ & -4.01037294 & 1.14230336 & -1.92772885 \\
\hline $\mathrm{C}$ & -1.89291025 & -2.16058968 & -3.14571226 \\
\hline $\mathrm{C}$ & -4.27787054 & 0.42453463 & 1.66474772 \\
\hline $\mathrm{C}$ & -0.61312730 & -2.78087411 & -2.81984715 \\
\hline $\mathrm{C}$ & -1.56581825 & -0.86538674 & -3.73701485 \\
\hline $\mathrm{C}$ & -4.45443267 & 1.23855765 & 0.51682007 \\
\hline $\mathrm{C}$ & -0.45974674 & -3.62963610 & -1.69028326 \\
\hline $\mathrm{C}$ & -2.40129383 & 0.27726159 & -3.58245882 \\
\hline $\mathrm{C}$ & -4.56746515 & 0.56126966 & -0.74521819 \\
\hline $\mathrm{C}$ & -1.63922106 & -3.85340903 & -0.89323571 \\
\hline $\mathrm{C}$ & -3.57612087 & 0.08455164 & -2.78246994 \\
\hline $\mathrm{C}$ & -4.51681357 & -0.86737169 & -0.87106893 \\
\hline $\mathrm{C}$ & -2.95021274 & -3.26383661 & -1.20960802 \\
\hline $\mathrm{C}$ & -3.90629582 & -1.19401510 & -2.16613278 \\
\hline $\mathrm{C}$ & -3.09806406 & -2.38706290 & -2.37191085 \\
\hline $\mathrm{C}$ & -3.42948016 & 0.83798113 & 2.74202419 \\
\hline $\mathrm{C}$ & 0.44600064 & -1.87985156 & -3.19144109 \\
\hline $\mathrm{C}$ & -0.14529990 & -0.70798253 & -3.75553320 \\
\hline $\mathrm{C}$ & -3.90032297 & 2.53550955 & 0.54104780 \\
\hline $\mathrm{C}$ & 0.81266869 & -3.65004872 & -1.05830601 \\
\hline $\mathrm{C}$ & -1.79807628 & 1.55075546 & -3.62940203 \\
\hline $\mathrm{C}$ & -3.36975554 & 2.42770558 & -1.90372558 \\
\hline
\end{tabular}




\begin{tabular}{|c|c|c|c|}
\hline $\mathrm{C}$ & -2.75119921 & 2.08666795 & 2.71376188 \\
\hline $\mathrm{C}$ & 1.68896055 & -1.81981702 & -2.50522715 \\
\hline $\mathrm{C}$ & 0.49383320 & 0.56679748 & -3.69765250 \\
\hline $\mathrm{C}$ & -3.35923297 & 3.14113596 & -0.67618057 \\
\hline $\mathrm{C}$ & 0.95242361 & -3.81804417 & 0.36684403 \\
\hline $\mathrm{C}$ & -2.28945143 & 2.64444894 & -2.79647664 \\
\hline $\mathrm{C}$ & -2.25703193 & 3.97834894 & -0.31815611 \\
\hline $\mathrm{C}$ & 2.13694209 & -3.10470555 & 0.79720336 \\
\hline $\mathrm{C}$ & -1.18478139 & 3.48299123 & -2.43543509 \\
\hline $\mathrm{C}$ & -2.12798019 & 3.90876663 & 1.12798486 \\
\hline $\mathrm{C}$ & 2.73469342 & -2.53536188 & -0.37008502 \\
\hline $\mathrm{C}$ & -0.00354857 & 2.91572495 & -3.05617367 \\
\hline $\mathrm{C}$ & -1.10268908 & 4.08655173 & -1.14707503 \\
\hline $\mathrm{C}$ & -3.09689162 & 2.97014139 & 1.65038384 \\
\hline $\mathrm{C}$ & 1.90259379 & -2.80520925 & -1.50951742 \\
\hline $\mathrm{C}$ & -0.36576229 & 1.69296909 & -3.73549630 \\
\hline $\mathrm{C}$ & -0.90623431 & 4.03431424 & 1.73176085 \\
\hline $\mathrm{C}$ & 3.41189527 & -1.32053606 & -0.28409841 \\
\hline $\mathrm{C}$ & 1.23098710 & 3.02215046 & -2.46300924 \\
\hline $\mathrm{C}$ & 0.21620294 & 4.21342202 & -0.50366783 \\
\hline $\mathrm{C}$ & 0.29065959 & 4.22074764 & 0.91361935 \\
\hline $\mathrm{C}$ & 3.56987407 & -0.65356007 & 0.94887783 \\
\hline $\mathrm{C}$ & 1.37423788 & 3.71492028 & -1.18154436 \\
\hline $\mathrm{C}$ & -1.42188033 & 2.17446531 & 3.32626046 \\
\hline $\mathrm{C}$ & 2.38845975 & -0.52924668 & -2.43391694 \\
\hline $\mathrm{C}$ & 1.79386960 & 0.66029226 & -3.03514463 \\
\hline $\mathrm{C}$ & -0.56933960 & 3.21794065 & 2.88195527 \\
\hline $\mathrm{C}$ & 3.29358042 & -0.34357582 & -1.35433717 \\
\hline
\end{tabular}




\begin{tabular}{|c|c|c|c|}
\hline $\mathrm{C}$ & 2.16633964 & 1.92840725 & -2.51087548 \\
\hline $\mathrm{C}$ & 1.37956878 & 3.60503595 & 1.60688545 \\
\hline $\mathrm{C}$ & 3.92809763 & 0.82615230 & 0.69201320 \\
\hline $\mathrm{C}$ & 2.46970981 & 3.12932645 & -0.49037367 \\
\hline $\mathrm{C}$ & 2.44714003 & 2.96020011 & 0.92306980 \\
\hline $\mathrm{C}$ & 0.85838061 & 3.04809038 & 2.84718138 \\
\hline $\mathrm{C}$ & 3.57321113 & 0.93559650 & -0.79570539 \\
\hline $\mathrm{C}$ & 2.99852918 & 2.04559523 & -1.34037859 \\
\hline $\mathrm{C}$ & 5.44084812 & 1.16302377 & 1.00243724 \\
\hline $\mathrm{H}$ & 5.58161372 & 2.22817382 & 0.78936077 \\
\hline $\mathrm{H}$ & 5.58662545 & 1.00759756 & 2.07646900 \\
\hline $\mathrm{C}$ & 6.41972232 & 0.32967760 & 0.20146207 \\
\hline $\mathrm{C}$ & 6.87414423 & -0.89701021 & 0.69155137 \\
\hline $\mathrm{C}$ & 7.76804536 & -1.68315033 & -0.05036227 \\
\hline $\mathrm{C}$ & 8.19999243 & -1.21761655 & -1.29506703 \\
\hline $\mathrm{C}$ & 7.75864580 & 0.01109147 & -1.80832478 \\
\hline $\mathrm{C}$ & 6.86698171 & 0.77489659 & -1.05082000 \\
\hline $\mathrm{H}$ & 6.53355353 & -1.24658680 & 1.66143585 \\
\hline $\mathrm{H}$ & 8.89409264 & -1.81809849 & -1.87535979 \\
\hline $\mathrm{H}$ & 6.51889278 & 1.72811573 & -1.43569304 \\
\hline $\mathrm{C}$ & 8.25618745 & 0.49956344 & -3.15805883 \\
\hline $\mathrm{H}$ & 9.33500989 & 0.69541144 & -3.12640866 \\
\hline $\mathrm{H}$ & 8.07300307 & -0.25083371 & -3.93586423 \\
\hline $\mathrm{H}$ & 7.75030618 & 1.42486509 & -3.44937977 \\
\hline $\mathrm{C}$ & 8.24636370 & -3.01713714 & 0.49718454 \\
\hline $\mathrm{H}$ & 8.99523799 & -3.46464554 & -0.16301450 \\
\hline $\mathrm{H}$ & 8.69434077 & -2.89334717 & 1.49005727 \\
\hline $\mathrm{H}$ & 7.40950973 & -3.71998428 & 0.59051286 \\
\hline
\end{tabular}

